\title{
Efficacy of Woodchip Biochar and Brown Coal Waste as Stable Sorbents for Abatement of Bioavailable Cadmium, Lead and Zinc in Soil
}

\author{
C. Amoah-Antwi (iD • J. Kwiatkowska-Malina • E. Szara • \\ S. Thornton • O. Fenton • G. Malina
}

Received: 19 July 2020 / Accepted: 22 September 2020 / Published online: 3 October 2020

(C) The Author(s) 2020

\begin{abstract}
Organic sorbents alter physicochemical soil properties and mitigate heavy metal (HM) bioavailability. However, some sorbents are labile and, therefore, introduce the risk of HM release into soil after mineralisation. Before field application, new stable organic sorbents such as woodchip biochar (BIO) and brown coal waste (BCW) need to be tested and compared with standard organic amendments like farmyard manure (FYM). An incubated pot experiment was conducted to investigate the efficacy of FYM, BIO and $\mathrm{BCW}$ (added to soil in pots at 5 and $10 \% \mathrm{w} / \mathrm{w}$ ) to alter soil physicochemical properties and mitigate bioavailability of $\mathrm{Cd}, \mathrm{Pb}$ and $\mathrm{Zn}$ spiked in treatments at different doses (in $\mathrm{mg} \mathrm{kg}^{-1}$ ); 0 (not spiked), 1 (1 Cd, $70 \mathrm{~Pb}, 100$
\end{abstract}

C. Amoah-Antwi $(\bowtie) \cdot$ J. Kwiatkowska-Malina Faculty of Geodesy and Cartography, Warsaw University of Technology, Warsaw, Poland

e-mail: collins.amoah-antwi@pw.edu.pl

E. Szara

Department of Agricultural Chemistry, Institute of Agriculture, Warsaw University of Life Sciences, Warsaw, Poland

\section{S. Thornton}

Kroto Research Institute, University of Sheffield, Sheffield S10 2TN, UK

O. Fenton

Environmental Research Centre, Teagasc, Johnstown Castle, Co. Wexford, Ireland

G. Malina

AGH University of Science and Technology, Krakow, Poland
$\mathrm{Zn})$ and $2(3 \mathrm{Cd}, 500 \mathrm{~Pb}, 700 \mathrm{Zn})$, and incubated for 9 weeks. At the end of the experiment, the EDTAextractable HM fractions, $\mathrm{pH}$, cation exchange capacity (CEC) and specific surface area (SSA, to check trends) were determined in all treated soils. Results showed that FYM, BCW and BIO generally improved all soil properties (except reduced $\mathrm{pH}$ from $\mathrm{BCW}$ and apparent SSA reduction from FYM) and accounted for respective maximum abatements of $\mathrm{Cd}(50.2,69.9$ and $25.5 \%)$, $\mathrm{Pb}$ (34.2, 64.3 and 17.4\%) and $\mathrm{Zn}(14.9,17.7$ and $11.8 \%$ ) bioavailability in soil. FYM and BCW were more effective at $10 \% \mathrm{w} / \mathrm{w}$ especially in the low contaminated soil, whereas the highest efficacy for BIO was at $5 \% \mathrm{w} / \mathrm{w}$ and in the high contaminated soil. The efficacies of sorption by the organic sorbents varied for different $\mathrm{HMs}$ and were in the orders: $\mathrm{BCW}>$ $\mathrm{FYM}>\mathrm{BIO}$ for $\mathrm{Cd}$, FYM $>\mathrm{BCW}>\mathrm{BIO}$ for $\mathrm{Pb}$ and $\mathrm{BIO}>\mathrm{BCW}>\mathrm{FYM}$ for $\mathrm{Zn}$. Soil $\mathrm{pH}$ and $\mathrm{CEC}$ were strongly correlated with HM bioavailability in all treatments and implied that immobilisation of HMs occurred via complex formation, ion exchange and $\mathrm{pH}$-dependent specific adsorption. All three sorbents were beneficial as soil amendments, and in terms of HM mitigation, BCW had the highest efficacy, followed by FYM and then BIO. Considering the documented high soil stability of $\mathrm{BCW}$ and $\mathrm{BIO}$, these results are promising for further trialling at field scale.

Keywords Immobilisation - Sorption · Bioavailability · Complex formation $\cdot$ Ion exchange $\cdot$ Pot experiment 


\section{Introduction}

Soil is a major sink for heavy metal(loid)s (HMs) which are released into the environment from diverse geogenic and anthropogenic sources and processes (Malina 2004; Lwin et al. 2018). Unlike other environmental contaminants (e.g. pesticides), most HMs are non-biodegradable and therefore exhibit a high degree of persistence in soil with increased toxicity to humans, fauna and flora (Wuana and Okieimen 2011). The choice of remediation technique for HM-contaminated soils depends on the planned land use and the targeted remediation percentage (e.g. total mitigation versus $\%$ mitigation to comply with guideline values) (Gomiero 2016; Beesley et al. 2015).

The use of biochar and brown coal waste (BCW) for improving the physicochemical and biological characteristics of soil to promote HM sorption and immobilisation is a growing research area (AmoahAntwi et al. 2020). The immobilising effect of these porous organic materials on HMs can be attributed to increases in soil $\mathrm{pH}$, cation exchange capacity (CEC) and specific surface area (SSA) (Kwiatkowska et al. 2006; Sokołowska et al. 2007; Lwin et al. 2018). Biochar and BCW are highly carbonised recalcitrant materials with high organic matter (OM) and humic acid contents and therefore promote the formation of a higher proportion of stable soil aggregates (e.g. organo-metallic complexes and precipitates) compared with other conventional organic sorbents (e.g. compost and FYM) (Beesley et al. 2015). Even though a range of studies have reported significant reductions in HM bioavailability using conventional organic sorbents, their large labile OM pools are indicative of high mineralisation rates and tendency to release HMs into soil (Shaha et al. 2012; Placek et al. 2017). Generally, in soil amended with processed and stable OM sources, metals are easily transformed from their exchangeable forms to more stable organic phases (Lwin et al. 2018). Biochar and BCW have abundant negatively charged functional groups (e.g. phenol and carboxyl compounds) which progressively accumulate in soil during humification and are known as integral components of organometallic complexation reactions (Turgay et al. 2011).

Biochar produced from different feedstock materials can affect the mobility of different HMs in diverse ways (Lomaglio et al. 2017), the extent of which is also dictated by soil type. For example, biochars derived from agricultural wastes significantly immobilised $\mathrm{Pb}$, $\mathrm{Zn}$ and $\mathrm{Cu}$ but increased As and Sb mobility (Ahmad et al. 2017). The same study found the low-temperature biochars to be more effective in alkaline soils, whereas the high-temperature types in acidic soils. Brown coal waste, on the other hand, is reportedly effective for mitigating bioavailability of HMs in acidic soils, but its use could progress with further drops in soil $\mathrm{pH}$ (Kwiatkowska-Malina and Maciejewska 2013; Simmler et al. 2013). As a result, BCW can be used along with liming to ameliorate soil acidity to enhance sorption efficacy (Karczewska et al. 1996). However, this can aggravate the risk of releasing previously sorbed $\mathrm{HMs}$ into soil solution (Loganathan et al. 2012) owing to competition with the added $\mathrm{Ca}$ (from liming) for binding sites in the soil complex, especially if soil $\mathrm{pH}$ is not substantially increased. Other studies have incorporated crops (e.g. maize and winter rye) into the amended soil and found varying positive outcomes of biochar and BCW amendments on HM bioavailability (Skłodowski et al. 2006; Alaboudi et al. 2019). However, despite a plethora of research on biochar, there is still lack of coherence over its efficacy for the sorption of different HMs in a range of soils (Khan et al. 2015; Woldetsadik et al. 2016; Lomaglio et al. 2017). On the other hand, $\mathrm{BCW}$ is a slowly emerging soil amendment, and therefore, its effects on HMs are not yet fully elucidated (Amoah-Antwi et al. 2020).

To ensure the best possible outcomes from biochar and $\mathrm{BCW}$ applications in terms of mitigating $\mathrm{HM}$ contamination, supplementary studies will be needed to provide evidence-based scientific approaches which can be scaled up to field studies. The present pot-scale incubation experiment was conducted on bare soil amended with conifer woodchip biochar (BIO) and BCW, and FYM, and then artificially contaminated with a mixture of $\mathrm{Cd}, \mathrm{Pb}$ and $\mathrm{Zn}$. Since FYM is a widely used soil sorbent with known effects on HM release in soil, it was included as a comparative treatment. This study is designed for restoration of both low and high contaminated soils to high-value terrestrial biomes including arable lands, forests and grasslands. The objectives of the study were to (i) evaluate the effects of $\mathrm{BIO}, \mathrm{BCW}$ and FYM amendments on the bioavailability of $\mathrm{Cd}$, $\mathrm{Pb}$ and $\mathrm{Zn}$ in soil and (ii) assess the relationship between selected physicochemical soil properties (pH and CEC) and HM bioavailability. 


\section{Materials and Methods}

\subsection{Soil and Organic Sorbents}

Soil was collected (to a depth of $0-30 \mathrm{~cm}$ ) from a previously cultivated (triticale) field at the Skierniewice Experimental Station in central Poland $\left(20^{\circ} 34^{\prime} \mathrm{E}, 51^{\circ}\right.$ $\left.58^{\prime} \mathrm{N}\right)$. The soil, a loamy sand ( $87 \%$ sand, $6 \%$ silt, $7 \%$ clay) haplic luvisol (WRB 2015), was air-dried for 3 days, rolled and then stones and plant litter were removed. The soil was crushed in a ceramic mortar and passed through a 2-mm dry sieve. A $25 \mathrm{~g}$ soil sample was taken and physicochemical properties were determined (Table 1).

The BIO was made using conifer wood chips via low-temperature $\left(280^{\circ} \mathrm{C}\right)$ flash pyrolysis (temperature increase of $10{ }^{\circ} \mathrm{C} / \mathrm{min}$; residence time of $10 \mathrm{~min}$ ) undertaken at a commercial facility (Fluid Spółka Akcyjna, Poland). The applied pyrolysis technology allows to achieve stable production in autothermity when the average temperature inside the reactor remains above $630^{\circ} \mathrm{C}$. This temperature enables the maintenance of an autothermal anaerobic carbonisation process in retorts with an average temperature above $260{ }^{\circ} \mathrm{C}$. The relatively low pyrolysis temperature used in this study was to lower energy demands and thus to produce a more sustainable and cost-effective biochar for soil remediation purposes. The BCW was obtained from the Bełchatów Coal Mine located in central Poland and had a moisture content of $34 \%$, whereas FYM (a mixture of straw and cow dung with a moisture content of $78 \%$ ) was from a livestock farm in Skierniewice, Poland. All organic sorbents were air-dried for 3 days. From each of the dried sorbents, $25 \mathrm{~g}$ was sampled, crushed gently in a ceramic mortar and passed through a 2-mm sieve and then analysed for physicochemical characteristics (Table 1).

\subsection{Pot-Scale Incubation Experiment}

Sixty-three plastic pots $($ diameter $\times$ height $=5 \times 15 \mathrm{~cm}$ ) were filled with $125 \mathrm{~g}$ of sieved soil (bulk density of $1.75 \mathrm{~g} / \mathrm{cm}^{3}$, water holding capacity (WHC) of $27 \%$ $\mathrm{m} / \mathrm{m}$ ) using a funnel. There were seven treatments which are comprised of three organic sorbents added to soil in the pots at two rates, 5\% w/w (BIO-1, BC-1 and FYM1) and $10 \% \mathrm{w} / \mathrm{w}$ (BIO-2, BC-2 and FYM-2), which are equivalent to 26.25 and $52.50 \mathrm{t} \mathrm{ha}^{-1}$, respectively, in addition to an unamended control. After mixing evenly, these resulted in respective WHCs (in \% $\mathrm{m} / \mathrm{m}$ ) of 33,26 , 40, 34, 28, 44 and 27.

The amended soils were then spiked with a ternary mixture of $\mathrm{HMs}(\mathrm{Cd}, \mathrm{Pb}$ and $\mathrm{Zn})$ to create three definite ecological levels of multi-element contamination, where the highest dose of each metal is close to the upper threshold prescribed in the guidelines for HMs in soil and groundwater (NEPC 1999; Toth et al. 2016). Cadmium, $\mathrm{Pb}$ and $\mathrm{Zn}$ were spiked separately into each of the amended soils in the pots at different doses using their respective aqueous solutions, $\mathrm{Cd}\left(\mathrm{NO}_{3}\right)_{2} \times 4 \mathrm{H}_{2} \mathrm{O}$, $\mathrm{Pb}\left(\mathrm{NO}_{3}\right)_{2}$ and $\mathrm{ZnSO}_{4} \times 7 \mathrm{H}_{2} \mathrm{O}$, and then blended uniformly. Doses 1 and 2 reflected, respectively, the following concentrations in soil (in $\mathrm{mg} \mathrm{kg}^{-1}$ ) $-1(\mathrm{Cd}), 70$ $(\mathrm{Pb}), 100(\mathrm{Zn})$; and $3(\mathrm{Cd}), 500(\mathrm{~Pb})$ and $700(\mathrm{Zn})$ whereas dose 0 represented the unspiked treatments. All treatments were performed in three replicates. Throughout the experiment, soil water content was adjusted to $50 \%$ of the WHC estimated for each of the treatments. Such water content was chosen because it has been shown to be suitable for plant growth in light soils

Table 1 Characteristics of soil and organic sorbents studied in the pot experiment

\begin{tabular}{|c|c|c|c|c|c|c|c|c|c|c|c|c|c|c|c|}
\hline \multirow[t]{2}{*}{ Materials } & \multicolumn{2}{|l|}{$\mathrm{pH}$} & \multicolumn{4}{|c|}{ Exchangeable cations } & \multirow[t]{2}{*}{ CEC } & \multicolumn{6}{|l|}{ Total } & \multirow[t]{2}{*}{$\mathrm{C} / \mathrm{N}$} & \multirow[t]{2}{*}{ SSA } \\
\hline & $\mathrm{H}_{2} \mathrm{O}$ & $\mathrm{KCl}$ & $\mathrm{Ca}$ & $\mathrm{Na}$ & $\mathrm{K}$ & $\mathrm{Mg}$ & & $\mathrm{Cd}$ & $\mathrm{Pb}$ & $\mathrm{Zn}$ & $\mathrm{C}$ & $\mathrm{N}$ & $\mathrm{S}$ & & \\
\hline & & & \multicolumn{4}{|c|}{$\mathrm{cmol} \mathrm{kg}^{-1}$} & $\mathrm{cmol} \mathrm{kg}^{-1}$ & \multicolumn{3}{|c|}{$\mathrm{mg} \mathrm{kg}^{-1}$} & $\%$ & & & & $\mathrm{~m}^{2} \mathrm{~g}^{-1}$ \\
\hline Soil & 6.53 & 5.57 & 0.46 & 0.05 & 0.26 & 0.16 & 0.92 & $<0.01$ & 0.01 & 0.40 & 0.72 & 0.07 & 0.01 & 10.29 & 0.75 \\
\hline $\mathrm{BCW}$ & 5.85 & 5.40 & 18.66 & 0.22 & 3.24 & 2.23 & 24.35 & $<0.01$ & 0.03 & 0.25 & 43.80 & 0.53 & 1.26 & 82.64 & 2.15 \\
\hline $\mathrm{BIO}$ & 10.02 & 9.49 & 25.56 & 0.37 & 3.47 & 1.98 & 31.15 & $<0.01$ & 0.01 & 0.40 & 82.60 & 0.87 & 0.05 & 94.94 & 4.80 \\
\hline FYM & 9.66 & 8.75 & 13.00 & 5.85 & 17.96 & 10.47 & 47.28 & n.d. & 0.03 & 2.68 & 35.30 & 2.25 & 0.85 & 15.69 & 1.01 \\
\hline
\end{tabular}

$C E C$ cation exchange capacity, $S S A$ specific surface area, $B C W$ brown coal waste, $B I O$ conifer wood chips biochar, $F Y M$ farmyard manure, n.d. not detected 
(Xue et al. 2017). The pots were set up on tables in a well-ventilated laboratory at room temperature for 9 weeks of incubation to ensure maximum sorption and equilibrium. Typically, adsorption of metals in incubated soils increases rapidly in the first $24 \mathrm{~h}$ followed by equilibrium between 4 and 8 weeks (Casagrande et al. 2004; Wuana and Okieimen 2011; Anemana et al. 2020).

After incubation, pots were emptied, and soil was airdried and then homogenised for determination of physicochemical properties. Soil $\mathrm{pH}$ was measured potentiometrically in $1 \mathrm{M} \mathrm{KCl}(1: 2.5 w / v)$ (Kabała et al. 2016) and the $\mathrm{CEC}$ in $1 \mathrm{M} \mathrm{CH}_{3} \mathrm{COONH}_{4}$ buffered solution at pH 7.0 (Zgorelec et al. 2019). For statistical determination of the relationships between soil $\mathrm{pH}$ and other parameters, $\mathrm{pH}$ was converted to hydrogen ion concentration $\left(\left[\mathrm{H}^{+}\right]\right)$by the formula:

$\left[\mathrm{H}^{+}\right]=10^{-\mathrm{pH}}$

In addition, the SSA was analysed for one sample per treatment using the Brunauer-Emmett- Teller (BET) method to examine the trends.

\subsection{Extraction of Heavy Metals}

The European Commission's Standards, Measurements and Testing programme (SM\&T) for soil recommends the single-step extraction using ethylenediaminetetraacetic acid (EDTA) as the certification approach for determining the bioavailable fraction of metals in soil (Olaniran et al. 2013). Even though dilute solutions of unbuffered salts (e.g. $\mathrm{CaCl}_{2}$ and $\mathrm{NH}_{4} \mathrm{NO}_{3}$ ) are also suitable for extracting labile HMs from soil, a chelating organic reagent was generally preferred in this study because in addition to the exchangeable- and carbonate-bound metals it can also dislodge the reducible fractions (Bakircioglu et al. 2011). These metal fractions can be immobilised by organic sorbents, especially the highly stable types which have low mineralisation rates and pose less risks of releasing bound HMs into soil.

The extraction of the bioavailable fractions of $\mathrm{Cd}, \mathrm{Pb}$ and $\mathrm{Zn}$ was conducted as follows: firstly, $5 \mathrm{~g}$ of soil from each incubated pot was placed in $200 \mathrm{~mL}$ sample tubes; then, $50 \mathrm{~mL}$ of $0.05 \mathrm{M}$ EDTA was added; and tubes were placed on a rotary shaker and operated at $30 \mathrm{rpm}$ for $1 \mathrm{~h}$ at room temperature. The extracts were separated from soil residue into centrifuge tubes and centrifuged at $3000 \mathrm{rpm}$ for $10 \mathrm{~min}$. Following centrifugation, the supernatant was passed through a vacuum filter, stored at $4{ }^{\circ} \mathrm{C}$ until metal analysis by atomic absorption spectrometry (AAS, Thermo Scientific ${ }^{\mathrm{TM}}$ $i C E$ 3000, Germany). The percentage reduction (\%Red) of the bioavailable fractions of HMs in the treated soils relative to the unamended control was calculated as follows:

$\%$ Red $=\frac{\text { Unamended control-Treatment }}{\text { Unamended control }} \times 100$

\subsection{Statistical Analyses}

The Kruskal-Wallis rank sum test was carried out to determine the statistical differences in treatment groups of bioavailable $\mathrm{HM}$ fractions (across all doses of $\mathrm{Cd}, \mathrm{Pb}$ and $\mathrm{Zn}$ ), $\mathrm{pH}$ and CEC of soil followed by Nemenyi's test for multiple comparisons (Tukey) at a significance level of $p<0.05$. Regression analyses were done using Spearman's rank correlation coefficients $(r)$ for pairwise comparison $(p<0.05, p<0.01$ and $p<0.001)$ of multiple parameters comprising the bioavailable HM fractions and soil properties ( $\mathrm{pH}$ and CEC). All statistical analyses were carried out using $\mathrm{R}$ software (version 1.3.959).

\section{Results and Discussion}

\subsection{Effects of Organic Sorbents on Soil Properties}

The effects of organic sorbents on soil $\mathrm{pH}$ and CEC after incubation are presented in Table 2. The results reveal significant $(p<0.05)$ increases in soil $\mathrm{pH}$ from the respective 5 and $10 \% \mathrm{w} / \mathrm{w}$ treatments of BIO $(1.9,2.3 \mathrm{pH}$ units) and FYM (2.9, $3.1 \mathrm{pH}$ units) compared with the control. On the other hand, $\mathrm{BCW}$ amendment led to marginal, insignificant $(p<0.05)$ reductions in $\mathrm{pH}$ (0.2, $0.4 \mathrm{pH}$ units). The higher amendment rate of all treatments appeared to have a greater impact (though, not significantly different), irrespective of whether soil $\mathrm{pH}$ increased or decreased. The $\mathrm{pH}$ increases from $\mathrm{BIO}$ were consistent with its documented high liming capacity (Lwin et al. 2018; Yuan et al. 2011), especially considering the acidic nature of the original soil (Table 1). Although the ash content of BIO was not quantified, increases in $\mathrm{pH}$ from biochar, particularly the low-temperature types, are attributed to the release 
Table 2 Effects of organic sorbents on $\mathrm{pH}$ and CEC of soil (unspiked samples after incubation)

\begin{tabular}{lll}
\hline Treatment & pH in KCl & $\begin{array}{l}\text { CEC } \\
\mathrm{cmol} \mathrm{kg}^{-1}\end{array}$ \\
\hline Control & $5.54 \pm 0.08 \mathrm{c}$ & $0.92 \pm 0.13 \mathrm{e}$ \\
BCW-1 & $5.34 \pm 0.08 \mathrm{c}$ & $5.93 \pm 0.35 \mathrm{~cd}$ \\
BCW-2 & $5.19 \pm 0.18 \mathrm{c}$ & $7.73 \pm 0.87 \mathrm{c}$ \\
BIO-1 & $7.40 \pm 0.27 \mathrm{~b}$ & $4.61 \pm 0.68 \mathrm{~d}$ \\
B1O-2 & $7.80 \pm 0.21 \mathrm{~b}$ & $5.44 \pm 0.29 \mathrm{~cd}$ \\
FYM-1 & $8.40 \pm 0.17 \mathrm{a}$ & $20.27 \pm 1.35 \mathrm{~b}$ \\
FYM-2 & $8.59 \pm 0.14 \mathrm{a}$ & $36.07 \pm 2.31 \mathrm{a}$ \\
LSD $_{0.05}$ & 0.48 & 3.09 \\
\hline
\end{tabular}

CEC cation exchange capacity, $B C W$ brown coal waste, $B I O$ conifer wood chips biochar, FYM farmyard manure. Treatments at levels 1 (BCW-1, BIO-1 and FYM-1) and 2 (BCW-2, BIO-2 and FYM-2) represent organic amendments at 5 and $10 \% \mathrm{w} / \mathrm{w}$, respectively. $\mathrm{LSD}_{0.05}$ - least significant difference at the level $\alpha=$ 0.05 . Values are treatment means $( \pm \mathrm{SD})$. Sample sizes are $\mathrm{pH}$ $(n=3)$ and CEC $(n=3)$ for all treatments. Treatments that do not share a letter are significantly different according to Nemenyi's test for multiple comparisons (Tukey) at a significant level of $p<0.05$

of groups such as carbonates of alkali and alkaline earth metals, silica and sesquioxides in the form of ashes to soil (Nigussie et al. 2012). Due to the high acidneutralising capacity of ashes, biochar is often recommended as a substitute liming material for soil amendment (Arocena and Opio 2003). Even though the diverse functional groups in humic acids from $\mathrm{BCW}$ provide additional reactive sites in soil, they are composed mostly of acidic carboxylic and phenolic groups which confer acidity to the material. Therefore, the drop in soil $\mathrm{pH}$ which was greater at the higher $\mathrm{BCW}$ rate was conceivable, especially without liming. This is in agreement with Simmler et al. (2013) who reported reduced soil $\mathrm{pH}$ (0.1-0.6 units) from BCW (lignite) amendment. However, BCW has a high buffering capacity and considering that the $\mathrm{pH}$ drops were low $(<$ 0.5 units), this may imply a potential for long-term stabilisation of soil pH (Krol-Domańska and Smolinska 2012). Again, haplic luvisols reportedly have strong buffering properties (Kwiatkowska et al. 2008), and they could also be a reason for the insignificant $(p<0.05) \mathrm{BCW}$ impacts on soil $\mathrm{pH}$ while also suggesting that the $\mathrm{pH}$ increases from BIO and FYM could have been higher in other less-buffered acidic soils. Our results are also consistent with the findings by Singh et al. (2009) who observed a significant increase in the $\mathrm{pH}$ of an acidic soil from FYM amendment. The researchers also suggested co-application with lime for enhanced mitigation of acidity. Though the release of organic acids from labile OM decomposition reportedly leads to reduced soil $\mathrm{pH}$ (Aziz et al. 2017), FYM, which has a higher mineralisation potential, proved to be a better ameliorant of soil acidity than the more recalcitrant sorbents (i.e. BIO and $\mathrm{BCW}$ ). Other studies, however, have shown that FYM can also be a useful neutralising agent for alkaline soil amendment (Brar et al. 2015; Mahmood et al. 2017). Consequently, co-application of carbonised organic sorbents, especially BCW, with FYM can be given due consideration to exploit their complimentary benefits (i.e. $\mathrm{pH}$ regulation and buffering) in different soils. The $\left[\mathrm{H}^{+}\right]$across BIO and FYM treatments had strong negative correlations with CEC $(r=$ -0.77 and -0.90 ; Tables 3 and 4 , respectively) indicating that their addition to soil may have increased the exchange sites and capacity for $\mathrm{Al}$ and Fe binding, leading to $\mathrm{pH}$ increases. This correlation was strongly positive in the BCW treatments $(r=0.75$, Table 5) and suggests that the resulting low soil $\mathrm{pH}$ may have been caused by masking of the benefit of a large CEC (as above) by the acidic nature of BCW.

The CEC of soil responded positively to increasing application rates of organic sorbent and resulted in multi-fold increases from BCW (6, 8 times), $\mathrm{BIO}(5,6$ times) and FYM (22, 39 times), compared with the control. Generally, CEC has been shown to increase if the exchangeable $\mathrm{Ca}$ content of the amendment material is higher than that of the target soil. In this study, the exchangeable $\mathrm{Ca}$ contents of all treatments were at least 28-fold higher than the original soil (Table 1), thus resulting in the high CEC increases across treatments. In a 12-week incubation experiment, biochar induced CEC increases only in soils that had lower initial exchangeable $\mathrm{Ca}$ contents, whereas CEC decreased with higher starting exchangeable $\mathrm{Ca}$ contents across 10 different soils (Hailegnaw et al. 2019). In the upper horizon of light mineral soils, it is estimated that by increasing OM content (e.g. via organic amendment), the CEC increases by $20-95 \%$ (Oades et al. 1989). This may be a reason why CECs of the highly labile FYM soil treatments were markedly higher than from $\mathrm{BIO}$ and $\mathrm{BCW}$, which are extensively processed with relatively smaller fractions of available OM. Again, the high increases in CEC from the FYM amendment could be due to the 
Table 3 Correlation among soil properties ( $\mathrm{pH}$ and $\mathrm{CEC}$ ) and concentrations of bioavailable fractions of $\mathrm{Cd}, \mathrm{Pb}$ and $\mathrm{Zn}$ in $\mathrm{BIO}-\mathrm{amended}$ soils

$\left[\mathrm{H}^{+}\right] \quad$ CEC $\quad$ Cd dose 0 Cd dose $1 \quad$ Cd dose $2 \quad$ Pb dose $0 \quad$ Pb dose $1 \quad$ Pb dose 2 Zn dose 0 Zn dose $1 \quad$ Zn dose 2

\begin{tabular}{|c|c|c|c|c|c|c|c|c|c|c|c|}
\hline$\left[\mathrm{H}^{+}\right]$ & 1.00 & & & & & & & & & & \\
\hline CEC & $-0.77 * * *$ & 1.00 & & & & & & & & & \\
\hline Cd dose 0 & -0.33 & 0.33 & 1.00 & & & & & & & & \\
\hline Cd dose 1 & -0.02 & 0.05 & $0.82 *$ & 1.00 & & & & & & & \\
\hline Cd dose 2 & $0.62 * *$ & -0.45 & 0.48 & $0.60 *$ & 1.00 & & & & & & \\
\hline $\mathrm{Pb}$ dose 0 & $0.78 * *$ & $-0.87 * *$ & -0.27 & 0.00 & 0.50 & 1.00 & & & & & \\
\hline $\mathrm{Pb}$ dose 1 & 0.48 & -0.23 & 0.33 & $0.50 *$ & $0.82 * *$ & 0.33 & 1.00 & & & & \\
\hline $\mathrm{Pb}$ dose 2 & $0.68 * *$ & $-0.58 * *$ & -0.25 & -0.07 & 0.57 & $0.57 *$ & 0.77 & 1.00 & & & \\
\hline $\mathrm{Zn}$ dose 0 & -0.32 & 0.38 & $0.98 * * *$ & 0.75 & 0.50 & -0.28 & 0.40 & -0.18 & 1.00 & & \\
\hline $\mathrm{Z}$ n dose 1 & $0.70 * *$ & $-0.67 * *$ & 0.28 & 0.58 & $0.82 *$ & $0.72 *$ & 0.53 & 0.42 & 0.22 & 1.00 & \\
\hline Zn dose 2 & $0.73 * *$ & $-0.52 *$ & 0.33 & 0.60 & $0.90 * * *$ & $0.55^{*}$ & $0.75 * *$ & $0.57 *$ & 0.32 & $0.92 * *$ & 1.00 \\
\hline
\end{tabular}

$\left[H^{+}\right]$hydrogen ion concentration (converted from $\mathrm{pH}$ ), $C E C$ cation exchange capacity, BIO wood chip biochar. Doses 0,1 and 2 of each heavy metal represent the concentrations of bioavailable fractions in unspiked, low contaminated and high contaminated soils, respectively Correlation coefficients were determined by Spearman's rank correlation $(p<0.05)$ from parameters with sample sizes: $n=18$ (Cd dose 0 , Cd dose 1, Cd dose 2, Pb dose 0, Pb dose 1, Pb dose 2, Zn dose 0, Zn dose 1 and $\mathrm{Zn}$ dose 2) and $n=9$ (CEC, pH). Significance at $p<0.05$, $p<0.01$ and $p<0.001$ are presented as $* * *$, and $* * *$, respectively

formation of a high organic colloid proportion in soil (Nkechi et al. 2013). This is supported by Dhiman et al. (2019) who reported that CEC was higher in the topsoil due to a higher organic $\mathrm{C}$ content than in the sub-surface soil. Despite this, FYM reportedly decreased CEC of an acidic soil $(0-15 \mathrm{~cm})$ which then increased when FYM was applied as a composite amendment with biochar (Gautam et al. 2017). Increases in CEC from BIO could be due to its high SSA and the presence of variable charges which tend to increase base saturation, while the complete dissociation of the carboxylic groups of OM may be

Table 4 Correlation among soil properties ( $\mathrm{pH}$ and CEC) and concentrations of bioavailable fractions of Cd, $\mathrm{Pb}$ and $\mathrm{Zn}$ in FYM-amended soils

\begin{tabular}{|c|c|c|c|c|c|c|c|c|c|c|c|}
\hline & {$\left[\mathrm{H}^{+}\right]$} & CEC & Cd dose 0 & Cd dose 1 & Cd dose 2 & $\mathrm{~Pb}$ dose 0 & $\mathrm{~Pb}$ dose 1 & $\mathrm{~Pb}$ dose 2 & $\mathrm{Zn}$ dose 0 & Zn dose 1 & $\mathrm{Zn}$ dose 2 \\
\hline$\left[\mathrm{H}^{+}\right]$ & 1.00 & & & & & & & & & & \\
\hline CEC & $-0.90 * *$ & 1.00 & & & & & & & & & \\
\hline Cd dose 0 & $0.77 * *$ & $-0.67 * *$ & 1.00 & & & & & & & & \\
\hline Cd dose 1 & 0.87 & $-0.93 * * *$ & $0.65^{*}$ & 1.00 & & & & & & & \\
\hline Cd dose 2 & $0.68 *$ & $-0.88 *$ & $0.68 *$ & $0.80^{*}$ & 1.00 & & & & & & \\
\hline $\mathrm{Pb}$ dose 0 & 0.68 & $-0.73^{*}$ & $0.70 *$ & $0.70^{* *}$ & 0.72 & 1.00 & & & & & \\
\hline $\mathrm{Pb}$ dose 1 & 0.62 & $-0.77 * *$ & 0.23 & $0.87 * * *$ & 0.60 & $0.58 * *$ & 1.00 & & & & \\
\hline $\mathrm{Pb}$ dose 2 & $0.53 * *$ & $-0.63 * *$ & $0.65^{*}$ & 0.73 & $0.77 * *$ & 0.40 & 0.50 & 1.00 & & & \\
\hline $\mathrm{Zn}$ dose 0 & 0.38 & -0.47 & 0.27 & 0.43 & 0.35 & 0.73 & 0.58 & 0.00 & 1.00 & & \\
\hline Zn dose 1 & 0.35 & -0.47 & 0.10 & 0.40 & 0.42 & $0.60 *$ & 0.62 & 0.03 & $0.87 * * *$ & 1.00 & \\
\hline Zn dose 2 & 0.57 & $-0.73^{*}$ & 0.70 & $0.70^{* *}$ & $0.80 *$ & $0.75^{*}$ & $0.57 *$ & 0.63 & 0.68 & 0.55 & 1.00 \\
\hline
\end{tabular}

$\left[\mathrm{H}^{+}\right]$hydrogen ion concentration (converted from $\mathrm{pH}$ ), $C E C$ cation exchange capacity, $F Y M$ farmyard manure. Doses 0,1 and 2 of each heavy metal represent the concentrations of bioavailable fractions in unspiked, low contaminated and high contaminated soils, respectively Correlation coefficients were determined by Spearman's rank correlation $(p<0.05)$ from parameters with sample sizes: $n=18$ (Cd dose 0 , $\mathrm{Cd}$ dose 1, Cd dose 2, $\mathrm{Pb}$ dose $0, \mathrm{~Pb}$ dose 1, $\mathrm{Pb}$ dose 2, $\mathrm{Zn}$ dose $0, \mathrm{Zn}$ dose 1 and $\mathrm{Zn}$ dose 2) and $n=9$ (CEC, pH). Significance at $p<0.05$, $p<0.01$ and $p<0.001$ are presented as $*, * *$, and $* * *$, respectively 
Table 5 Correlation among soil properties ( $\mathrm{pH}$ and $\mathrm{CEC}$ ) and concentrations of bioavailable fractions of $\mathrm{Cd}, \mathrm{Pb}$ and $\mathrm{Zn}$ in $\mathrm{BCW}$-amended soils

$\left[\mathrm{H}^{+}\right] \quad \mathrm{CEC} \quad \mathrm{Cd}$ dose $0 \quad \mathrm{Cd}$ dose $1 \quad \mathrm{Cd}$ dose $2 \quad \mathrm{~Pb}$ dose $0 \quad \mathrm{~Pb}$ dose $1 \quad \mathrm{~Pb}$ dose 2 Zn dose $0 \quad \mathrm{Zn}$ dose $1 \quad \mathrm{Zn}$ dose 2

\begin{tabular}{|c|c|c|c|c|c|c|c|c|c|c|c|}
\hline$\left[\mathrm{H}^{+}\right]$ & 1.00 & & & & & & & & & & \\
\hline CEC & $0.75^{*}$ & 1.00 & & & & & & & & & \\
\hline Cd dose 0 & -0.27 & -0.12 & 1.00 & & & & & & & & \\
\hline Cd dose 1 & $-0.75^{*}$ & $-0.85 * * *$ & 0.12 & 1.00 & & & & & & & \\
\hline $\mathrm{Cd}$ dose 2 & -0.72 & $-0.67 *$ & -0.03 & $0.58 * *$ & 1.00 & & & & & & \\
\hline $\mathrm{Pb}$ dose 0 & -0.62 & $-0.77^{*}$ & 0.07 & $0.67 * *$ & $0.73 * *$ & 1.00 & & & & & \\
\hline $\mathrm{Pb}$ dose 1 & $-0.97 *$ & $-0.73 * *$ & 0.23 & $0.68 * *$ & 0.63 & 0.48 & 1.00 & & & & \\
\hline $\mathrm{Pb}$ dose 2 & -0.30 & -0.45 & -0.65 & $0.58^{*}$ & $0.52 * * *$ & $0.55^{*}$ & 0.23 & 1.00 & & & \\
\hline $\mathrm{Zn}$ dose 0 & 0.58 & 0.40 & $-0.72 * * *$ & -0.50 & -0.07 & -0.02 & -0.63 & 0.35 & 1.00 & & \\
\hline $\mathrm{Zn}$ dose 1 & -0.18 & -0.42 & $-0.48^{*}$ & 0.47 & $0.67 * *$ & $0.67 *$ & 0.05 & $0.87^{*}$ & 0.48 & 1.00 & \\
\hline Zn dose 2 & -0.72 & -0.62 & $0.57^{*}$ & 0.42 & 0.38 & 0.27 & $0.82 *$ & -0.25 & $-0.78^{*}$ & -0.32 & 1.00 \\
\hline
\end{tabular}

$\left[\mathrm{H}^{+}\right]$hydrogen ion concentration (converted from $\mathrm{pH}$ ), $C E C$ cation exchange capacity, $B C W$ brown coal waste. Doses 0,1 and 2 of each heavy metal represent the concentrations of bioavailable fractions in unspiked, low-contaminated and high-contaminated soils, respectively Correlation coefficients were determined by Spearman's rank correlation $(p<0.05)$ from parameters with sample sizes: $n=18(\mathrm{Cd}$ dose 0 , Cd dose 1, Cd dose 2, Pb dose 0, Pb dose 1, Pb dose 2, Zn dose 0, Zn dose 1 and $\mathrm{Zn}$ dose 2) and $n=9$ (CEC, pH). Significance at $p<0.05$, $p<0.01$ and $p<0.001$ are presented as $*, * *$, and $* * *$, respectively

responsible for the observed effects from BCW (Yuan et al. 2011; Skodras et al. 2014).

Results from the BET measurements for the 5 and $10 \% \mathrm{w} / \mathrm{w}$ treatments were, respectively, as follows (in $\left.\mathrm{m}^{2} \mathrm{~g}^{-1}\right)$ : BCW $(0.77,0.99)$, BIO $(0.89,0.85)$ and FYM $(0.61,0.66)$, compared with the control $(0.75)$. These showed increases in SSA of soil by BCW $(2.7,32.0 \%)$ and $\mathrm{BIO}(18.7,13.3 \%)$, whereas reductions were found from the FYM $(18.7,12.0 \%)$ treatments, relative to the control. The presence of a highly porous structure of humified materials (i.e. BIO and $\mathrm{BCW}$ ) is primarily responsible for their high SSA, the lack of which could be responsible for the reverse effect from FYM amendment. In line with these findings, Arthur et al. (2015) reported that biochar amendment increased the SSA of a sandy loam soil. The stability of an amendment material is crucial for developing a stable micropore soil structure to sustain SSA increases along with enhancement of other physical soil properties (Chu et al. 2018). This highlights why the high stability of $\mathrm{BCW}$ and $\mathrm{BIO}$ was an important factor for their selection as tools for abatement of HMs in soil.

\subsection{Immobilisation of HMs by Organic Sorbents}

The total concentrations of $\mathrm{Cd}, \mathrm{Pb}$ and $\mathrm{Zn}$ in both the soil and organic sorbents are presented in Table 1. The use of organic sorbents as remediative agents in soil has been questioned due to claims that they could be sources of contaminants including HMs. However, unlike other studies (Hamid et al. 2018; Mbarki et al. 2020) which found high $\mathrm{HM}$ concentrations in some organic sorbents (up to $5.7 \mathrm{mg} \mathrm{kg}^{-1} \mathrm{Cd}, 12.9 \mathrm{mg} \mathrm{kg}^{-1} \mathrm{~Pb}$ and $116 \mathrm{mg} \mathrm{kg}^{-1} \mathrm{Zn}$ ), their contents in the sorbents used in this study were much lower and within acceptable range for use in soil systems (Barth et al. 2008). Figures 1, 2 and 3 show the EDTA-extractable fractions of $\mathrm{Cd}, \mathrm{Pb}$ and $\mathrm{Zn}$, respectively, from soils contaminated with a mixture of HMs spiked into soil at three doses. Given the low metal contribution from the soil and organic materials, the total HM contents at each dose are presented as their respective spiked concentrations. The total HM content of soil is an estimation of saturation and potential supply of metals to the solution phase (Rieuwerts et al. 1998) and, thus, can influence their bioavailability. This study therefore seeks to present the different doses as three distinct levels of metal release from bound to the exchangeable phase.

In the unspiked soil (dose 0 ), the bioavailable $\mathrm{Cd}$ in all treatments were several folds higher than the sum of total $\mathrm{Cd}$ in both soil and the organic sorbents for each of the treatments. Cadmium bioavailability in the 5 and $10 \% \mathrm{w} / \mathrm{w}$ treatments in most cases were, respectively, lower compared with the control by: BCW $(32.4,2.5 \%)$ and FYM $(19.3,27.2 \%)$ (Fig. 1a). On the other hand, bioavailability was $24.0 \%$ lower in the BIO-1 but $50.5 \%$ 


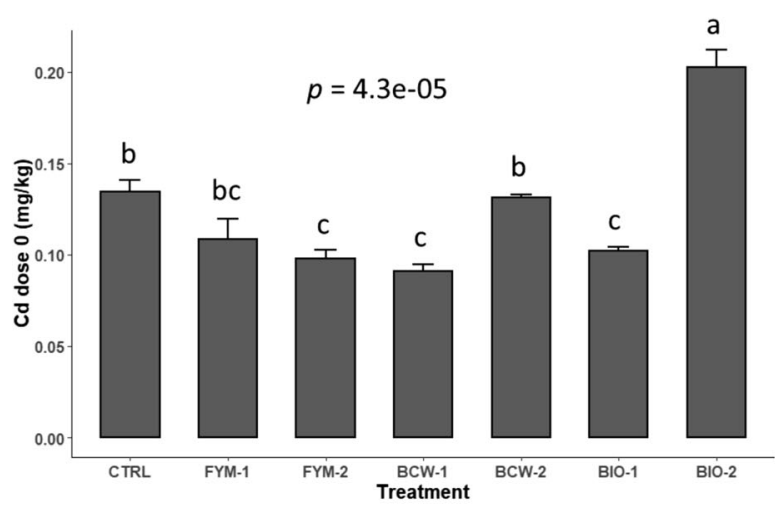

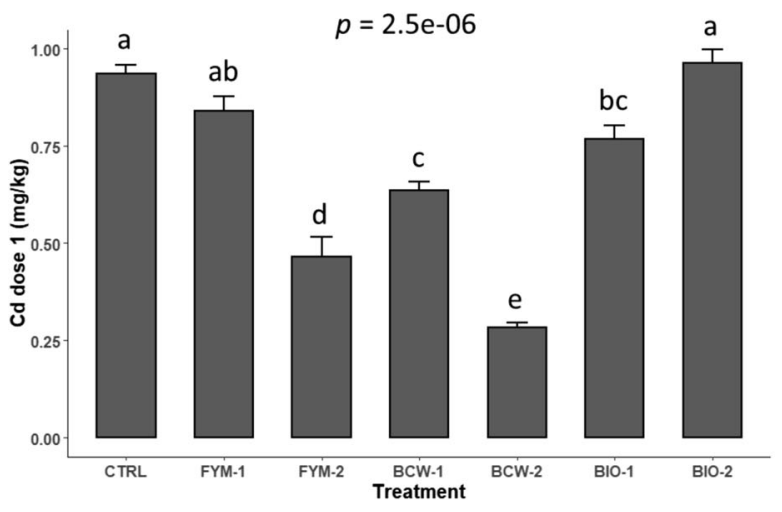

Fig. 1 Concentrations of the bioavailable fractions of $\mathrm{Cd}$ in soil contaminated by HMs at dose 0 (a), dose 1 (b) and dose 2 (c) after treatment by different organic materials. Values are treatment means ( $\pm \mathrm{se}$ ), $n=6$. Bars that do not share a letter are significantly different according to Nemenyi's test for multiple comparisons

higher in the BIO-2 treatments. Only the BCW-2 treatment was not significantly different from the control at $p<0.05$. In the soil with a low HM concentration (dose $1,1.0 \mathrm{mg} \mathrm{kg}^{-1} \mathrm{Cd}$ ), reductions in bioavailability from organic treatments compared with the control were BCW $(32.2,69.9 \%)$ and FYM $(10.2,50.3 \%)$ (Fig. 1b). There was also reduced bioavailability from BIO-1 (18.0\%), whereas BIO-2 led to a marginal increase (2.9\%). Apart from the BIO treatment (not significantly different, $p<0.05$, at the $10 \% \mathrm{w} / \mathrm{w}$ rate), an increasing amendment rate in the other treatments led to higher reductions in $\mathrm{Cd}$ bioavailability. In the high HMcontaminated soil (dose $2,3.0 \mathrm{mg} \mathrm{kg}^{-1} \mathrm{Cd}$ ), reductions in bioavailability compared with the control were $\mathrm{BCW}$ $(1.3,42.2 \%)$ and BIO $(25.5,9.3 \%)$ and FYM (10.2, $20.8 \%$ ), (Fig. 1c). The BCW-1 treatment was not significantly different $(p<0.05)$ from the control. The BCW-2 treatment was the most effective for Cd immobilisation and had the highest sorptive capacity in both

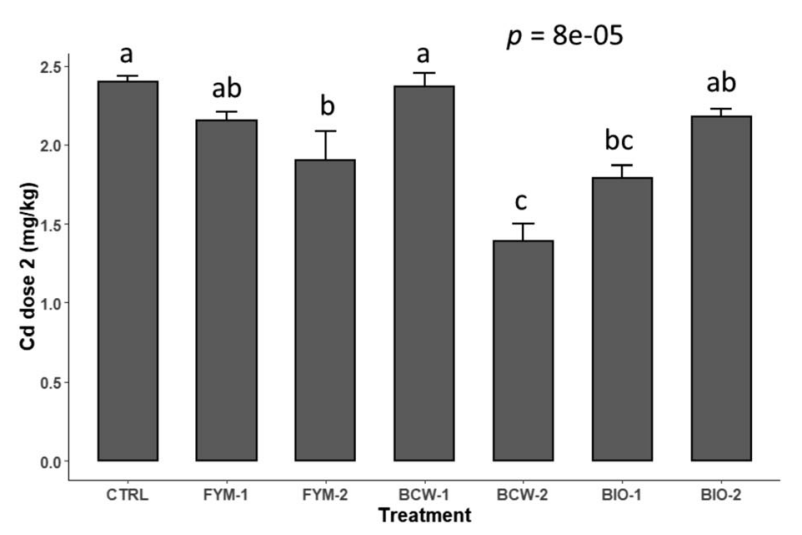

(Tukey) at a significant level of $p<0.05$. BCW brown coal waste, BIO conifer wood chips biochar, FYM farmyard manure. Treatments at levels 1 (BCW-1, BIO-1 and FYM-1) and 2(BCW-2, BIO-2 and FYM-2) represent organic amendments at 5 and $10 \%$ $\mathrm{w} / \mathrm{w}$, respectively

the low and high contaminated soils. This could also imply that at the higher $\mathrm{BCW}$ rate, there may have been corresponding increases in the OM content and reactive surfaces of soil which enhanced Cd sorption and complex formation. These observations are consistent with the findings from other pot studies which observed higher $\mathrm{Cd}$ immobilisation from increasing application rates of a BCW preparation, the so-called 'Rekulter', in a high contaminated soil by $54 \%$ (Skłodowski et al. 2006) and a low contaminated soil by $13 \%$ (Kwiatkowska 2006). In both cases, the reduction in $\mathrm{Cd}$ bioavailability was accompanied by increases in the organic carbon content and $\mathrm{pH}$ of soil. However, in the former study, rye was cultivated on the treated soils and may have contributed to the significantly higher reduction in Cd bioavailability via translocation. In contrast to $\mathrm{BCW}$, the lower application rate $(5 \% \mathrm{w} / \mathrm{w})$ of BIO had consistently higher sorptive capacity for $\mathrm{Cd}$ than the higher rate $(10 \% \mathrm{w} / \mathrm{w})$ in both the low and high 
contaminated soils. This is in agreement with the findings from other studies, such as that of Puga et al. (2015) who found $5 \% \mathrm{w} / \mathrm{w}$ biochar to be the most effective for $\mathrm{Cd}$ immobilisation in a contaminated technosol $\left(0.9 \mathrm{mg} \mathrm{kg}^{-1} \mathrm{Cd}\right)$ but indicated that sorption efficacy increased with increasing biochar rate (between 0 and $5 \% \mathrm{w} / \mathrm{w})$. Another study by Woldetsadik et al. (2016) which involved a silty loam with low $\mathrm{Cd}$ $\left(0.30 \mathrm{mg} \mathrm{kg}^{-1}\right)$ and sandy loam soil with high $\mathrm{Cd}$ $\left(2.58 \mathrm{mg} \mathrm{kg}^{-1}\right)$ contents found respective bioavailability reductions of 65 and $68 \%$ after cow manure biochar amendment. However, coffee husk biochar amendment of the same two soils led to respective bioavailability increases of 102 and $115 \%$. The study also found that treatments were slightly more effective in the high Cdcontaminated soil, which is in line with the findings from the present study where both BIO-1 and BIO-2 immobilised more $\mathrm{Cd}$ (7 and 12\%) in the high than low contaminated soils, respectively. Like $\mathrm{BCW}, \mathrm{Cd}$
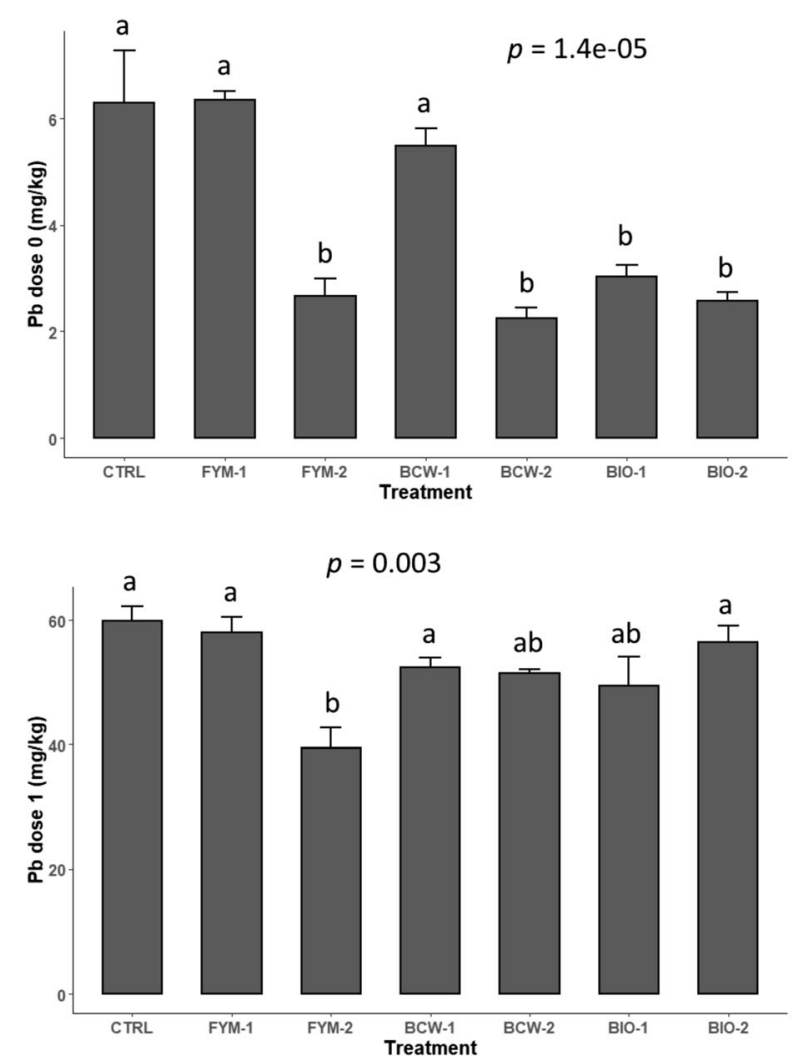

Fig. 2 Concentrations of the bioavailable fractions of $\mathrm{Pb}$ in soil contaminated by HMs at dose 0 (a), dose 1 (b) and dose 2 (c) after treatment by different organic materials. Values are treatment means ( $\pm \mathrm{se}$ ), $n=6$. Bars that do not share a letter are significantly different according to Nemenyi's test for multiple comparisons immobilisation increased at the higher application rate of FYM and was greater in the low contaminated soil. In a similar study, FYM applied at $10 \% \mathrm{w} / \mathrm{w}$ to a calcareous soil irrigated with HM-contaminated wastewater was the most efficient sorbent among a range of amendments (poultry manure, diammonium phosphate and triple super phosphate) and led to greater reductions in Cd bioavailability (Khan et al. 2012). However, maximum sorption was achieved after 30 days and there were subsequent increases in Cd bioavailability (days 45 and 90), which may be indicative of its release from organometallic complexes as a result of OM decomposition.

The bioavailable $\mathrm{Pb}$ concentrations in the unspiked soils (dose 0 ) across all treatments were also higher than the respective sum of total $\mathrm{Pb}$ in the soil and individual organic sorbents. However, compared with the control, $\mathrm{Pb}$ bioavailability was lower in the respective 5 and $10 \%$ $w / \mathrm{W}$ treatments of $\mathrm{BIO}(51.9,59.1 \%)$ (Fig. 2a). While $\mathrm{Pb}$ bioavailability was also lower at the higher

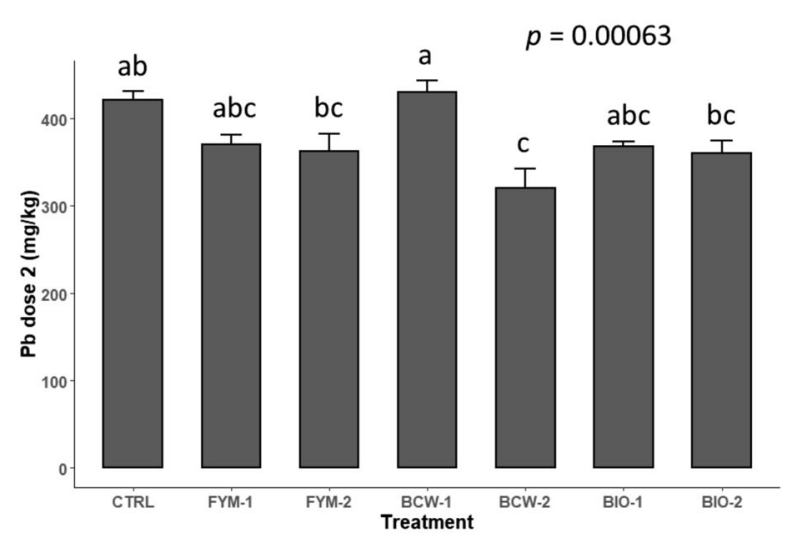

(Tukey) at a significant level of $p<0.05$. BCW brown coal waste, $\mathrm{BIO}$ conifer wood chips biochar, FYM farmyard manure. Treatments at levels 1 (BCW-1, BIO-1 and FYM-1) and 2(BCW-2, BIO-2 and FYM-2) represent organic amendments at 5 and $10 \%$ $w / \mathrm{w}$, respectively 
application rates of BCW (64.3\%) and FYM (57.6\%), there were no significant differences when applied at their lower rates, compared with the control. In the soil with a low $\mathrm{HM}$ concentration $\left(70 \mathrm{mg} \mathrm{kg}^{-1} \mathrm{~Pb}\right)$, organic sorbents, relative to the control, reduced $\mathrm{Pb}$ bioavailability by $\mathrm{BCW}(12.5,14.1 \%)$ and $\mathrm{BIO}(17.4,5.8 \%)$ and FYM $(3.2,34.2 \%)$ (Fig. 2b). At this level of contamination (dose 1), the trends in $\mathrm{Pb}$ sorption were similar to those found with $\mathrm{Cd}$ where the higher BCW and FYM and then lower BIO application rates were more effective than their corresponding alternative rates. The effects of BCW-1, BIO-2 and FYM-1 on Pb bioavailability were not significantly different $(p<0.05)$ from the control. All treatments of the high contaminated soil (500 $\mathrm{mg} \mathrm{kg}^{-1} \mathrm{~Pb}$ ) led to reduced $\mathrm{Pb}$ bioavailability compared with the control: $\mathrm{BCW}(2.1,14.0 \%)$, BIO $(14.7,15.9 \%)$ and FYM $(16.5,25.6 \%)$ (Fig. 2c). In agreement with these results, the FYM amendment of a calcareous sandy loam with 100, 200 and $400 \mathrm{mg} \mathrm{kg}^{-1}$ $\mathrm{Pb}$ after 30 days of incubation led to maximum $\mathrm{Pb}$ immobilisation in the low contaminated soil $(51 \%)$ through precipitation with $\mathrm{CaCO}_{2}$ (Aziz et al. 2017). While FYM was more effective than BIO which also accounted for higher $\mathrm{Pb}$ immobilisation than $\mathrm{BCW}$, an increasing application rate of all sorbents led to enhanced $\mathrm{Pb}$ sorption in the high contaminated soil. These results are consistent with the findings of Yang et al. (2016) who reported higher reductions (up to 20\%) in extractable $\mathrm{Pb}$ from an increasing bamboo biochar application rate in a sandy loam paddy soil with a high $\mathrm{Pb}$ concentration (527 mg kg-1), and Skłodowski et al. (2006) who found an increasing rate of Rekulter to be more effective for $\mathrm{Pb}$ immobilisation in a loamy sand soil $\left(\sim 120 \mathrm{mg} \mathrm{kg}^{-1} \mathrm{~Pb}\right)$. Despite this, other researchers have reported discrepancies in the effects of $\mathrm{BCW}$ and biochar on $\mathrm{Pb}$ bioavailability. For example, lignite fly ash amendment induced no further reduction in the bioavailable fractions of $\mathrm{Pb}$ beyond the $5 \% \mathrm{w} / \mathrm{w}$ application rate (Stouraiti et al. 2002), while there were no significant effects from BCW applied to soil at $0-10 \%$ $\mathrm{w} / \mathrm{w}$ (Uzinger et al. 2014). Khan et al. (2015) also reported that different biochars (from rice straw, rice husk and saw dust) had no significant sorptive effects on the bioavailable fraction of $\mathrm{Pb}$ in a non-calcareous soil $\left(14 \mathrm{mg} \mathrm{kg}^{-1} \mathrm{~Pb}\right)$.

Just as for $\mathrm{Cd}$ and $\mathrm{Pb}$, the EDTA-extractable fractions of $\mathrm{Zn}$ in the unspiked soil (dose 0 ) across all treatments were higher than the respective sum of total $\mathrm{Zn}$ in the soil and individual organic sorbents. Compared with the control, Zn bioavailability was lower in the BIO-1 $(42.6 \%)$ and FYM-2 (71.3\%), but higher in the BCW$1(330.8 \%), \mathrm{BCW}-2(70.9 \%), \mathrm{BIO}-2(189.62 \%)$ and FYM-1 (222.8\%) treatments (Fig. 3a). In the low contaminated soil (100 $\left.\mathrm{mg} \mathrm{kg}^{-1} \mathrm{Zn}\right), \mathrm{Zn}$ bioavailability was lower in BCW-2 (17.7\%), BIO-1 (11.7\%), BIO-2 $(9.9 \%)$ and FYM-2 (14.9\%) but higher in BCW-1 (12.2\%) and FYM-1 (24.7\%) treatments compared with the control $(p<0.05)$ (Fig. 3b). Zinc sorption by BCW and FYM was more effective at the higher application rate, whereas $\mathrm{BIO}$ at the lower rate. In the high contaminated soil (700 $\mathrm{mg} \mathrm{kg}^{-1} \mathrm{Zn}$ ), reductions in $\mathrm{Zn}$ bioavailability compared with the control were BCW (10.8, $5.8 \%)$, BIO $(11.8,8.3 \%)$ and FYM $(0.9,7.5 \%)$, (Fig. 3c). The BIO-1 and BCW-1 treatments were the most effective while FYM-1 failed to significantly $(p<0.05)$ immobilise Zn. In comparison, a 4-week pot incubation study involving FYM amendment (1, 2 and $3 \% w / w)$ of an alluvial clay soil led to reduced $\mathrm{Zn}$ bioavailability (up to $26 \%$ ) in the $2 \%$ treatment through precipitation with phosphates and carbonates released from OM decomposition (Sabir et al. 2014). On the other hand, Uzinger et al. (2014) found that $\mathrm{Zn}$ sorption increased at higher $\mathrm{BCW}$ rates $(0-10 \% \mathrm{w} / \mathrm{w})$ in an acidic soil with a range of low and high concentrations (0-1500 mg kg-1 $\mathrm{Zn}$ ). This appears to confirm our findings in the low contaminated soil where $\mathrm{Zn}$ sorption was greater at the higher $\mathrm{BCW}$ rate but also contradicts the observations in the high contaminated soil. Also in agreement with the present findings is a study by Zhou et al. (2017) which found the $5 \% \mathrm{w} / \mathrm{w}$ biochar be the most effective for $\mathrm{Zn}$ immobilisation $(29.8 \%)$ in a low contaminated soil (43.9 $\mathrm{mg} \mathrm{kg}^{-1} \mathrm{Zn}$ ). However, Namgay et al. (2010) reported that increasing wood biochar application $\left(0,5\right.$ and $\left.15 \mathrm{~g} \mathrm{~kg}^{-1}\right)$ increased the extractable $\mathrm{Zn}$ fractions in a sandy orthic tenosol with a similarly low $\mathrm{Zn}$ concentration $\left(50 \mathrm{mg} \mathrm{kg}^{-1}\right)$. However, on this occasion, the significant increases in $\mathrm{Zn}$ bioavailability were due to the high elemental content of the biochar and thus indicate the need for careful selection of biochar feedstock. A lower rate of walnut leaves biochar $\left(2 \% \mathrm{w} / \mathrm{w}, 600{ }^{\circ} \mathrm{C}\right)$ was found to reduce $\mathrm{Zn}$ bioavailability $(49.1 \%)$ in a heavily contaminated (> $2000 \mathrm{mg} \mathrm{kg}^{-1} \mathrm{Zn}$ ) calcareous soil (Kabiri et al. 2019), which again highlights how differences in biochar feedstock and soil concentrations of the target metal can influence amendment outcomes.

The mobility of the HMs in soil solution differs between the more soluble types (e.g. $\mathrm{Zn}$ and $\mathrm{Cd}$ ) and 


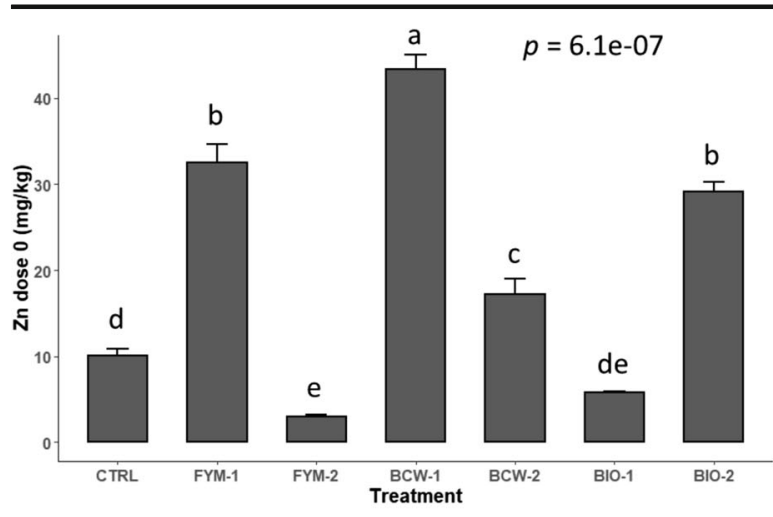

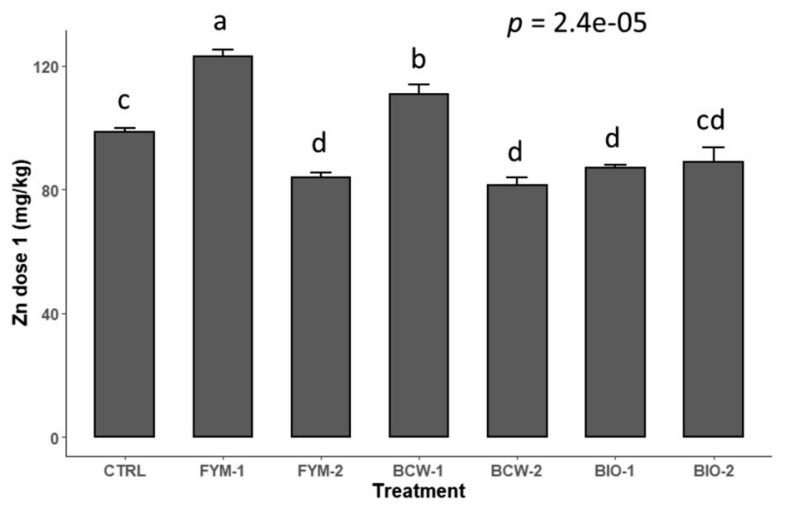

Fig. 3 Concentrations of the bioavailable fractions of $\mathrm{Zn}$ in soil contaminated by HMs at dose 0 (a), dose 1 (b) and dose 2 (c) after treatment by different organic materials. Values are treatment means ( $\pm \mathrm{se}$ ), $n=6$. Bars that do not share a letter are significantly different according to Nemenyi's test for multiple comparisons

$\mathrm{Pb}$, which tends to form strong complexes with soil (Moreno-Jiménez et al. 2016). The solubility of HMs is dictated in part by the extent of their association with organic components (e.g. humic acids), phyllosilicates and variable charge minerals (e.g. Fe, Mn, Al and $\mathrm{Ti}$ oxides) (Violante et al. 2010). Consequently, the effects of organic sorbents on HM immobilisation in this study varied considerably at each level of contamination. The efficacies of HM sorption were found to be in the orders of $\mathrm{BCW}>\mathrm{FYM}>\mathrm{BIO}$ for $\mathrm{Cd}, \mathrm{FYM}>\mathrm{BCW}>\mathrm{BIO}$ for $\mathrm{Pb}$ and $\mathrm{BIO}>\mathrm{BCW}>\mathrm{FYM}$ for $\mathrm{Zn}$. Generally, $\mathrm{BCW}$ and FYM were more effective at the $10 \% w / \mathrm{w}$, while $\mathrm{BIO}$ at the $5 \% \mathrm{w} / \mathrm{w}$ application rates. In addition to the distinctive mobility of each metal, variations in the surface functional groups of the organic sorbents may be responsible for the different sorption efficacies. The functional groups in materials with high humic acid contents (e.g. carbonised organic materials) being hard Lewis bases, are known to have higher affinities for $\mathrm{Pb}$ (a borderline hard Lewis acid) compared with $\mathrm{Cd}$ and

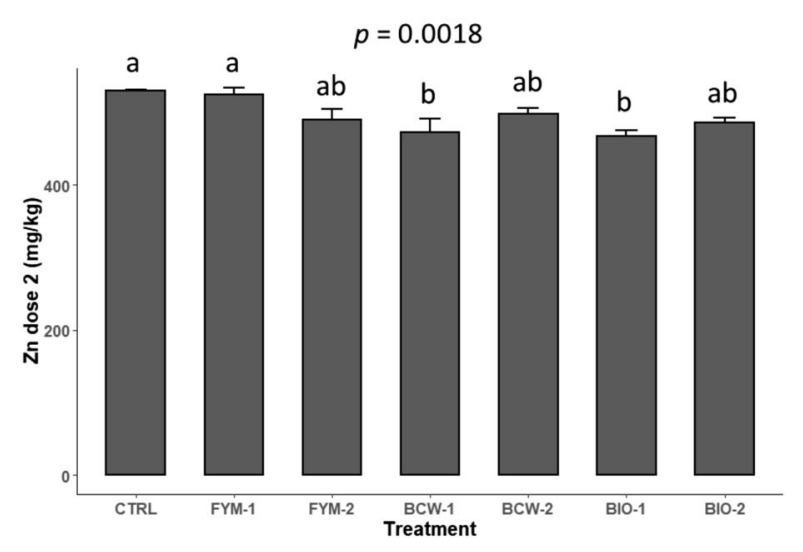

(Tukey) at a significant level of $p<0.05$. BCW brown coal waste, BIO conifer wood chips biochar, FYM farmyard manure. Treatments at levels 1 (BCW-1, BIO-1 and FYM-1) and 2 (BCW-2, BIO-2 and FYM-2) represent organic amendments at 5 and $10 \%$ $\mathrm{w} / \mathrm{w}$, respectively

Zn which are soft Lewis acids (Chaturvedi et al. 2006). Consequently, different studies (Stouraiti et al. 2002; Namgay et al. 2010; Yang et al. 2016) have found the efficiency of amendment with carbonised organic materials to be in the order of $\mathrm{Pb}>\mathrm{Cd} \geq \mathrm{Zn}$. This has been attributed the preferential sorption of $\mathrm{Pb}$ over $\mathrm{Cd}$ and $\mathrm{Zn}$ after incorporating organic sorbents. However, in this study, the efficacies of HM immobilisation by the sorbents, especially the carbonised types, were in the order of $\mathrm{Cd}>\mathrm{Pb}>\mathrm{Zn}$, in both the low and high contaminated soils. Sorption of $\mathrm{Cd}$ by organic materials is mainly through precipitation and interaction with the ubiquitous surface functional groups (phenolic, carbonyl and carboxyl) which may be higher in the carbonised sorbents due to their higher degree of humification (Kwiatkowska-Malina 2018; Chen et al. 2020). These compounds, along with possible changes in metal speciation during the incubation period may have influenced a higher $\mathrm{Cd}$ adsorption than $\mathrm{Pb}$, despite the odds. Organic sorbents release large amounts of phosphates 
and carbonates which form complexes and precipitates (e.g. the P-phase hopeite) on the outer surface or monodentate inner-sphere surface complex of $\mathrm{OM}$ with metals, primarily Zn (Qian et al. 2016). The low Zn sorption efficiencies across all treatments in this study seem to indicate that phosphate- and carbonate-linked mechanisms were not extrusive. Especially in the FYM treatments, the lower $\mathrm{Zn}$ immobilisation may have resulted from the formation of soluble organo-metallic complexes which increased metal availability in the solution phase (Aziz et al. 2017). The distinct surface chemistries across treatments and their sorptive capacities for each of the HMs in this study suggest that composite organic sorbents comprising of different combinations of FYM, BCW and BIO can be approbative for amendment of multi-element contaminated soils. Immobilisation of HMs by organic sorbents is known to be less efficient in multi-element soils than mono-element types due to competitive adsorption (Zhou et al. 2017). Thus, the sorptive efficiencies of FYM, BIO and BCW for each of the HMs measured in this study could be substantially higher in monometal contaminated soils. The increases in the extractable fractions of $\mathrm{Cd}, \mathrm{Pb}$ and $\mathrm{Zn}$ after incubation in the unspiked soil could not have been contributed by the organic sorbents, especially considering their substantially low HM contents. It is possible, however, that during incubation, there may have been metals of lithogenic origin previously unaccounted for by acid digestion, which were transiently released from strongly sorbed $\mathrm{Al}$ and $\mathrm{Fe}$ precipitates through temporal changes such as desorption or weathering (Violante et al. 2010). The reference to estimates of metals in acid digestates of soil as 'pseudo-total' fractions was perhaps clearly demonstrated through these analyses of the unspiked soil as the true total values were most likely many folds higher than estimated.

\subsection{Relationship Between HM Bioavailability and Soil Properties ( $\mathrm{pH}$ and CEC)}

Due to the extremely low concentrations of HMs in the unspiked soil and the erratic effects of organic sorbents on their stabilisation, the relationships between the bioavailable metal fractions and soil properties $(\mathrm{pH}$ and CEC) were inconsistent (Tables 3, 4 and5). Therefore, the discussions below will focus mainly on the relationships determined in the low (dose 1) and high (dose 2) contaminated soils. The studied organic sorbents modified soil $\mathrm{pH}, \mathrm{CEC}$ and SSA and thus influenced $\mathrm{HM}$ mobility. The transfer of $\mathrm{Cd}, \mathrm{Pb}$ and $\mathrm{Zn}$ cations from solution to solid phase in soil is somewhat linked to changes in these properties through processes such as physical adsorption, surface (co)precipitation (with carbonates, phosphates or silicates), ion exchange and complex formation with functional groups (Huang et al. 2016). There is gradual consensus building that the use of $\mathrm{pH}$ notation does not provide adequate quantitative evaluation of hydrogen ion activity in soil. Thus, for each treatment, $\left[\mathrm{H}^{+}\right]$was converted from $\mathrm{pH}$ and used for establishing correlations between the acid-base status and the concentration of bioavailable HM fractions in soil.

For BCW treatments, correlations between the $\left[\mathrm{H}^{+}\right]$ and bioavailable $\mathrm{HM}$ fractions were generally negative and very strong for $\mathrm{Pb}$ (dose 1 , significant at $p<0.05$ ), strong for $\mathrm{Cd}$ (doses 1 and 2) and $\mathrm{Zn}$ (dose 2), weak for $\mathrm{Pb}$ (dose 2) and very weak for $\mathrm{Zn}$ (dose 1) (Table 5). The correlations between the CEC and bioavailable $\mathrm{HM}$ fractions ranged from moderately negative to strongly negative for all metals at both doses 1 and 2 and found to be significant $(p<0.05)$ at both doses of $\mathrm{Cd}$ and dose 1 of $\mathrm{Pb}$. These results suggest that increasing soil CEC and $\left[\mathrm{H}^{+}\right]$(or decreasing $\mathrm{pH}$ ) were both associated with decreasing HM bioavailability in the BCW-treated soils. For the BIO treatments, correlations between the $\left[\mathrm{H}^{+}\right]$and bioavailable $\mathrm{HM}$ fractions were strongly positive for all HMs in the high contaminated soils and significant at $p<0.01$, whereas in the low contaminated soils, these were strongly positive for $\mathrm{Zn}$ and moderately positive for $\mathrm{Pb}$, while negligible for Cd (Table 3). Taken together, the relationship between $\left[\mathrm{H}^{+}\right]$and HM bioavailability was strongly positive. On the other hand, the CEC and bioavailable fractions of $\mathrm{HMs}$ at all doses were generally negatively correlated (especially for $\mathrm{Pb}$ and $\mathrm{Zn}$ ), with the only exception being $\mathrm{Cd}$ in the low contaminated soil where no correlation was found. These imply that increasing soil CEC and $\mathrm{pH}$ (or decreasing $\left[\mathrm{H}^{+}\right]$) were closely associated with reduced HM bioavailability for BIO treatments. For FYM treatments, both $\mathrm{pH}$ and CEC were found to be strongly negatively correlated with the bioavailable HM fractions in soil (Table 4) and, like for BIO treatments, increases in $\mathrm{pH}$ and CEC were linked with reduced HM bioavailability.

Results from this study corroborate findings from other researches which found that HM sorption was accompanied by $\mathrm{pH}$ increases when soil was amended 
by biochar and FYM (Uchimiya et al. 2010; Lwin et al. 2018) and reductions when BCW was used (Uzinger et al. 2014). The high pH of FYM (Table 1) along with the initial release of anions from decomposition which tend to consume protons in soil may be responsible for the increased pH (Opala et al. 2012) and HM immobilisation in the FYM treatments. In the case of BIO application, this could be due to a concurrent decline in aliphatic character and accretion of aromatic compounds in soil leading to hydrogen ion attenuation and enhanced metal sorption. By increasing carbonised proportions in soil, there is a non-stoichiometric release of cations which can mediate HM immobilisation through complexation and sorption via delocalized carbon $\pi$ electrons interaction (Polo and Utrilla 2002). Also, an increase in the net negative surface charge of soil may have resulted from the increasing solution $\mathrm{pH}$ in the $\mathrm{BIO}$ and FYM treatments and can explain the enhanced HM sorption. These suggest that the dominant mechanisms may include specific adsorption by surface ligands through covalent bonding and may be facilitated by a high soil SSA as observed in the BIO treatments. Since FYM reduced SSA of soil and limited the possibility of ligand-specific reactions, sorption of HMs was most likely non-specific. On the other hand, a reverse $\mathrm{pH}-$ dependent HM immobilisation was found in the BCW treatments compared with the FYM and BIO treatments in this study or other approaches found in the literature. This may have occurred via complex formation and surface adsorption by humic acids in $\mathrm{BCW}$, and it is understood that the latter mechanism is partly $\mathrm{pH}$ mediated. A plausible explanation for the high HM immobilisation by $\mathrm{BCW}$ even with the resultant acidic soil $\mathrm{pH}$, could be due to the presence of complimentary surface functional groups and the low optimum $\mathrm{pH}$ required for $\mathrm{Cd}, \mathrm{Pb}$ and $\mathrm{Zn}$ immobilisation. There is a critical $\mathrm{pH}$ range for each metal, usually smaller than two units, the so-called adsorption edge which is characterised by a rapid increase in metal sorption (Soares et al. 2011). According to Loganathan et al. (2012) the adsorption edge values for $\mathrm{Cd}, \mathrm{Pb}$ and $\mathrm{Zn}$ in soil are in the range of $\mathrm{pH}=4-6$ with that for $\mathrm{Cd}$ slightly lower than the others. An inference, somewhat, can be drawn from the observed high efficacy of BCW amendment for Cd immobilisation considering that the resultant soil $\mathrm{pH}$ values were all within the absorption edge range. However, $\mathrm{BIO}$ and FYM (and not BCW) were the most efficient treatments for $\mathrm{Zn}$ and $\mathrm{Pb}$, respectively, and thus indicate a disproportionate $\mathrm{pH}$ dependence that is contingent firstly on the type of organic material, and then, the intrinsic properties of the target metal. Other studies (Alamgir et al. 2011; Yuan et al. 2011; Uzinger et al. 2014; Anemana et al. 2020) have provided further evidence of bioavailable HM abatement through ion exchange following soil amendments with FYM, BIO and BCW. The CEC of soil provides an estimation of the amount of ion exchange sites (Rieuwerts et al. 1998), and thus the strong correlations between HM bioavailability and CEC in all treatments imply that ion exchange is a dominant immobilising mechanism.

The decomposition of OM (higher rates in FYM treatments) reduces the CEC and SSA of soil and can lead to increased mobility of HMs (Lwin et al. 2018) and again illustrates why the nature and stability of organic sorbents are such critical selection criteria for their application in long-term amelioration of HMcontaminated soils. The release of HMs into soil with FYM amendment after an initial period of immobilisation is attributed to a higher rate of OM decomposition and the formation of soluble organo-metallic complexes mediated via oxygen depletion and changing redox conditions of soil (Catlett et al. 2002; Aziz et al. 2017). On the other hand, mineralisation in processed organic materials is slow, and there is evidence of strong long-term buffering effects from $\mathrm{BCW}$ and $\mathrm{BIO}$ (linked to $\mathrm{pH}$ and/or CEC) which stabilise organometallic complexes in soil (Skłodowski et al. 2006; Bian et al. 2014; Lucchini et al. 2014) and reflect favourably on their immediate and long-term HM sorption efficacies. Due to their contradictory effects on soil $\mathrm{pH}, \mathrm{BIO}$ and $\mathrm{BCW}$ may have extensive uses in soils with varying levels of acidity. While $\mathrm{BCW}$ is naturally abundant and a wide range of biochar feedstock materials are locally available, the economic feasibility of their field-scale application is still being trialled (Amoah-Antwi et al. 2020) and, therefore, would require a gradual upscale of research to ascertain their suitability as alternatives to FYM and other organic sorbents.

\section{Conclusions}

All treatments investigated, i.e. FYM, BIO and BCW, improved soil $\mathrm{pH}, \mathrm{CEC}$ and SSA leading to enhanced $\mathrm{Cd}, \mathrm{Pb}$ and $\mathrm{Zn}$ sorption and mitigation. FYM, BCW and $\mathrm{BIO}$ amendments resulted in respective maximum reductions in bioavailability of Cd (50.2, 69.9 and 25.5\%), $\mathrm{Pb}$ (34.2, 64.3 and 17.4\%) and $\mathrm{Zn}(14.9,17.7$ and 
$11.8 \%)$. Surface chemistry of organic materials and inherent HM properties accounted for large variations in sorptive outcomes, thus resulting in maximum immobilisation of each HM by different organic sorbents (i.e. highest sorption of $\mathrm{Cd}, \mathrm{Pb}$ and $\mathrm{Zn}$ by $\mathrm{BCW}$, FYM and $\mathrm{BIO}$, respectively), albeit $\mathrm{BCW}$ was generally the most efficient. Both FYM and BCW had greater HM sorption at the higher application rate $(10 \% \mathrm{w} / \mathrm{w})$ especially in the low contaminated soil, whereas the highest efficacy for $\mathrm{BIO}$ was found at $5 \% \mathrm{w} / \mathrm{w}$ rate and greater in the high contaminated soil. Overall, sorption efficacies of the three HMs by the understudied organic sorbents were found to be in the order of $\mathrm{Cd}>\mathrm{Pb}>\mathrm{Zn}$. There were strong correlations between HM bioavailability and the selected soil properties ( $\mathrm{pH}$ and CEC) across all treatments which indicated that complex formation and ion exchange were prominent immobilising mechanisms in all three treatments, while specific adsorption via covalent bonding was additionally dominant in the BIO treatments. A unique HM immobilisation mechanism through soil $\mathrm{pH}$ reductions was observed in $\mathrm{BCW}$ treatments contrary to $\mathrm{pH}$ increases from FYM and $\mathrm{BIO}$ or conventional approaches found in the literature. This provides insights to the broad applicability of $\mathrm{BCW}$ and $\mathrm{BIO}$ in soils with varying levels of acidity. Finally, $\mathrm{BCW}$ and $\mathrm{BIO}$ were shown to be excellent sorbents and this along with their high soil stability, compared with FYM, make them promising tools for long-term amelioration of HM-contaminated soils.

Funding This research is part of a project that has received funding from the European Union's Horizon 2020 research and innovation programme under the Marie Skłodowska-Curie grant agreement No 675120.Data AvailabilityThe data that support the findings of this study are available from the corresponding author, [CAA], upon request.

\section{Compliance with Ethical Standards}

Conflict of Interest The authors declare that they have no conflict of interest.

Open Access This article is licensed under a Creative Commons Attribution 4.0 International License, which permits use, sharing, adaptation, distribution and reproduction in any medium or format, as long as you give appropriate credit to the original author(s) and the source, provide a link to the Creative Commons licence, and indicate if changes were made. The images or other third party material in this article are included in the article's Creative Commons licence, unless indicated otherwise in a credit line to the material. If material is not included in the article's Creative Commons licence and your intended use is not permitted by statutory regulation or exceeds the permitted use, you will need to obtain permission directly from the copyright holder. To view a copy of this licence, visit http://creativecommons.org/licenses/by/4.0/.

\section{References}

Ahmad, M., Lee, S. S., Lee, S. E., Al-Wabel, M. I., Tsang, D. C. W., \& Ok, Y. S. (2017). Biochar induced changes in soil properties affected immobilization/mobilization of metals/ metalloids in contaminated soils. Journal of Soils and Sediments, 17, 717-730. https://doi.org/10.1007/s11368015-1339-4.

Alaboudi, K. A., Ahmed, B., \& Brodie, G. (2019). Effect of biochar on $\mathrm{Pb}, \mathrm{Cd}$ and $\mathrm{Cr}$ availability and maize growth in artificial contaminated soil. Annals of Agricultural Sciences, 64(1), 95-102. https://doi.org/10.1016/j.aoas.2019.04.002.

Alamgir, M., Mg, K., \& Islam, M. (2011). Effects of farmyard manure on cadmium and lead accumulation in Amaranth (Amaranthus oleracea L.). Journal of Soil Science and Environmental Management, 2(8), 237-240.

Amoah-Antwi, C., Kwiatkowska-Malina, J., Thornton, S. F., Fenton, O., Malina, G., \& Szara, E. (2020). Restoration of soil quality using biochar and brown coal waste: a review. Science of the Total Environment, 722, 137852. https://doi. org/10.1016/j.scitotenv.2020.137852.

Anemana, T., Óvári, M., Szegedi, A., Uzinger, N., Rékási, M., Tatár, E., Yao, J., Streli, C., Záray, G., \& Mihucz, V. G. (2020). Optimization of lignite particle size for stabilization of trivalent chromium in soils. Soil and Sediment Contamination, 29(3), 272-291. https://doi.org/10.1080 $/ 15320383.2019 .1703100$.

Arocena, J. M., \& Opio, C. (2003). Prescribed fire-induced changes in properties of sub-boreal forest soils. Geoderma, 113, 116. https://doi.org/10.1016/S0016-7061(02)00312-9.

Arthur, E., Tuller, M., Moldrup, P., \& de Jonge, L. W. (2015). Effects of biochar and manure amendments on water vapor sorption in a sandy loam soil. Geoderma, 243, 175-182.

Aziz, M. A., Ahmad, H. R., Corwin, D. L., Sabir, M., Hakeem, R. K., \& Öztürk, M. (2017). Influence of farmyard manure on retention and availability of nickel, zinc and lead in metalcontaminated calcareous loam soils. Journal of Environmental Engineering and Landscape, 25(3), 289296. https://doi.org/10.3846/16486897.2016.1254639.

Bakircioglu, D., Kurtulus, Y. B., \& İbar, H. (2011). Comparison of extraction procedures for assessing soil metal bioavailability to wheat grains. Clean Soil Air Water, 39, 728-734.

Barth, J., Amlinger, F., Favoino, E., Siebert, S., Kehres, B., Gottschall, R., Bieker, M., Löbig, A., Bidlingmaier, W. (2008). Final report - compost production and use in the EU, European Commission, DG Joint Research Centre/ITPS.

Beesley, L., Moreno-Jimenez, E., Fellet, G., Carrijo, L., \& Sizmur, T. (2015). Biochar and heavy metals. In J. Lehmann \& S. Joseph (Eds.), Biochar for environmental management: science, technology and implementation (2nd ed., pp. 563-594). London: Earthscan. 
Bian, R. J., Joseph, S., Cui, L. Q., Pan, G. X., Li, L. Q., Liu, X. Y., et al. (2014). A three-year experiment confirms continuous immobilization of cadmium and lead in contaminated paddy field with biochar amendment. Journal of Hazardous Materials, 272, 121-128. https://doi.org/10.1016/j. jhazmat.2014.03.017.

Brar, B. S., Singh, J., Singh, G., \& Kaur, G. (2015). Effects of long-term application of inorganic and organic fertilizers on soil organic carbon and physical properties in maize-wheat rotation. Agronomy, 5, 220-238. https://doi.org/10.3390 /agronomy5020220.

Casagrande, J. C., Jordão, C. B., Alleoni, L. R. F., \& Camargo, O. A. (2004). Copper desorption in a soil with variable charge. Scientia Agricola, 61(2), 196-202.

Catlett, K. M., Heil, D. M., Lindsay, W. L., \& Ebinger, M. H. (2002). Soil chemical properties controlling zinc2+ activity in 18 Colorado soils. Soil Science Society of America Journal, 66, 1182-1189. https://doi.org/10.2136 /sssaj2002.118.

Chaturvedi, P. K., Seth, C. S., \& Misra, V. (2006). Sorption kinetics and leachability of heavy metal from the contaminated soil amended with immobilizing agent (humus soil and hydroxyapatite). Chemosphere, 64, 1109-1114. https://doi. org/10.1016/j.chemosphere.2005.11.077.

Chen, D., Wang, X., Wang, X., Feng, K., Su, J., \& Dong, J. (2020). The mechanism of cadmium sorption by sulphurmodified wheat straw biochar and its application cadmiumcontaminated soil. Science of the Total Environment, $714(20), 136550$. https://doi.org/10.1016/j. scitotenv.2020.136550.

Chu, G., Zhao, J., Huang, Y., Zhou, D., Liu, Y., Wu, M., Peng, H., Zhao, Q., Pan, B., \& Steinberg, C. (2018). Phosphoric acid pretreatment enhances the specific surface areas of biochars by generation of micropores. Environmental Pollution, 240, $1-9$.

Dhiman, D., Sharma, R., Sankhyan, N. K., Sepehya, S., Sharma, S. K., \& Kumar, R. (2019). Effect of regular application of fertilizers, manure and lime on soil health and productivity of wheat in an acid Alfisol. Journal of Plant Nutrition, 42(19), $2507-2521$. https://doi org/10.1080 /01904167.2019.1659317.

Gautam, D. K., Bajracharya, R. M., \& Sitaula, B. K. (2017). Effects of biochar and farmyard manure on soil properties and crop growth in an agroforestry system in the Himalaya. Sustainable Agriculture Research, 6, 74. https://doi. org/10.22004/ag.econ.265169.

Gomiero, T. (2016). Soil degradation, land scarcity and food security: reviewing a complex challenge. Sustainability, 8 , 281. https://doi.org/10.3390/su8030281.

Hailegnaw, N. S., Mercl, F., Pracke, K., Száková, J., \& Tlustoš, P. (2019). Mutual relationships of biochar and soil pH, CEC, and exchangeable base cations in a model laboratory experiment. Journal of Soils and Sediments, 19, 2405-2416.

Hamid, Y., Tang, L., Wang, X., Bilal, H., Yaseen, M., Yaseen, M., Aziz, M. Z., \& Yang, X. (2018). Immobilization of cadmium and lead in contaminated paddy field using inorganic and organic additives. Scientific Reports, 8, 17839. https://doi. org/10.1038/s41598-018-35881-8.

Huang, M., Zhu, Y., Li, Z., Huang, B., Luo, N., Liu, C., \& Zeng, G. (2016). Compost as a soil amendment to remediate heavy metal-contaminated agricultural soil: mechanisms, efficacy, problems, and strategies. Water, Air, and Soil Pollution, 227, 359. https://doi.org/10.1007/s11270-016-3068-8.

IUSS Working Group WRB (2015). World Reference Base for Soil Resources 2014, update 2015. International soil classification system for naming soils and creating legends for soil maps. World Soil Resources Reports No. 106. FAO, Rome.

Kabała, C., Musztyfaga, E., Galka, B., Labunska, D., \& Manczynska, P. (2016). Conversion of soil pH 1: $2.5 \mathrm{KCl}$ and 1: $2.5 \mathrm{H}_{2} \mathrm{O}$ to $1: 5 \mathrm{H}_{2} \mathrm{O}$ : conclusions for soil management, environmental monitoring, and international soil databases. Polish Journal of Environmental Studies, 25, 647653.

Kabiri, P., Motaghian, H., \& Hosseinpur, A. (2019). Effects of walnut leaves biochars on lead and zinc fractionation and phytotoxicity in a naturally calcareous highly contaminated soil. Water, Air, and Soil Pollution, 230, 263. https://doi. org/10.1007/s11270-019-4316-5.

Karczewska, A., Chodak, A., \& Kaszubkiewicz, J. (1996). The suitability of brown coal as a sorbent for heavy metals in polluted soils. Applied Geochemistry, 11, 343-346. https://doi.org/10.1016/0883-2927(95)00043-7.

Khan, M. J., Azeem, M. T., Jan, M. T., \& Perveen, S. (2012). Effect of amendments on chemical immobilization of heavy metals in sugar mill contaminated soils. Soil and Environment, 31, 55-66.

Khan, S., Waqas, M., Ding, F., Shamshad, I., Arp, H. P. H., \& Li, G. (2015). The influence of various biochars on the bioaccessibility and bioaccumulation of PAHS and potentially toxic elements to turnips (Brassica rapa, L.). Journal of Hazardous Materials, 300, 243-253.

Krol-Domańska, K., \& Smolinska, B. (2012). Advantages of lignite addition in purification process of soil polluted by heavy metals. Biotechnology and Food Science, 76, 51-58.

Kwiatkowska, J. (2006). The effect of organic amendments on the phytoavailability of heavy metals in polluted soil. Ecohydrology and Hydrobiology, 6(1-4), 181-186.

Kwiatkowska, J., Sokołowska, Z., \& Maciejewska, A. (2006). Selected physical and chemical properties for evaluating brown coals used for soil reclamation. International Agrophysics, 20(2), 121-128.

Kwiatkowska, J., Provenzano, M. R., \& Senesi, N. (2008). Longterm effects of brown coal-based amendment on the properties of soil humic acids. Geoderma, 148, 200-205.

Kwiatkowska-Malina, J. (2018). Functions of organic matter in polluted soils: the effect of organic amendments on phytoavailability of heavy metals. Applied Soil Ecology, 123, 542-545. https://doi.org/10.1016/j.apsoil.2017.06.021.

Kwiatkowska-Malina, J., \& Maciejewska, A. (2013). Uptake of heavy metals by darnel multifloral (Lolium multiflorum Lam.) at diverse soil reaction and organic matter content. Soil Science Annual, 64(1), 19-23. https://doi.org/10.2478 /ssa-2013-0000.

Loganathan, P., Vigneswaran, S., Kandasamy, J., \& Naidu, R. (2012). Cadmium sorption and desorption in soils: a review. Critical Reviews in Environmental Science and Technology, 42(5), 489-533.

Lomaglio, T., Hattab-Hambli, N., Bret, A., Miard, F., Trupiano, D., Scippa, G. S., Motelica-Heino, M., Bourgerie, S., \& Morabito, D. (2017). Effect of biochar amendments on the mobility and (bio) availability of $\mathrm{As}, \mathrm{Sb}$ and $\mathrm{Pb}$ in a 
contaminated mine technosols. Geochemical Exploration, 182(B), 138-148.

Lucchini, P., Quilliam, R., DeLuca, T. H., Vamerali, T., \& Jones, D. L. (2014). Does biochar application alter heavy metal dynamics in agricultural soil? Agriculture, Ecosystems and Environment, 184, 149-157.

Lwin, C. S., Seo, B.-H., Kim, H.-U., Owens, G., \& Kim, K.-R. (2018). Application of soil amendments to contaminated soils for heavy metal immobilization and improved soil quality - a critical review. Journal of Soil Science and Plant Nutrition, 64(2), 156-167. https://doi.org/10.1080 /00380768.2018.1440938.

Mahmood, F., Khan, I., Ashraf, U., Shahzad, T., Hussain, S., Shahid, M., Abid, M., \& Ullah, S. (2017). Effects of organic and inorganic manures on maize and their residual impact on soil physico-chemical properties. Journal of Soil Science and Plant Nutrition, 17, 22-32. https://doi.org/10.4067/S071895162017005000002.

Malina, G. (2004). Eco-toxicological and environmental problems associated with the former chemical plant in Tarnowskie Góry -Poland. Toxicology, 205(3), 157-172.

Mbarki, S., Skalicky, M., Talbi, O., Chakraborty, A., Hnilicka, F., Hejnak, V., Zivcak, M., Brestic, M., Cerda, A., \& Abdelly, C. (2020). Performance of Medicago sativa grown in clay soil favored by compost or farmyard manure to mitigate salt stress. Agronomy, 10, 94.

Moreno-Jiménez, E., Fernández, J. M., Puschenreiter, M., Williams, P. N., \& Plaza, C. (2016). Availability and transfer to grain of $\mathrm{As}, \mathrm{Cd}, \mathrm{Cu}, \mathrm{Ni}, \mathrm{Pb}$ and $\mathrm{Zn}$ in a barley agri-system: impact of biochar, organic and mineral fertilizers. Agriculture, Ecosystems and Environment, 219, 171-178.

Namgay, T., Singh, B., \& Singh, B. P. (2010). Influence of biochar application to soil on the availability of $\mathrm{As}, \mathrm{Cd}, \mathrm{Cu}, \mathrm{Pb}$, and $\mathrm{Zn}$ to maize (Zea mays L.). Australian Journal of Soil Research, 48, 638-647.

NEPC, National Environment Protection Council. (1999). National environment protection (assessment of site contamination) measure: Schedule B(1). Guideline on the investigation levels for soil and groundwater, Australia.

Nigussie, A., Kissi, E., Misganaw, M., \& Ambaw, G. (2012). Effect of biochar application on soil properties and nutrient uptake of lettuces (Lactuca sativa) grown in chromium polluted soils. American-Eurasian Journal of Agricultural and Environmental Sciences, 12(3), 369-376.

Nkechi, M. E., Emmanuel, N. O. I., Ishaku, Y. A., \& Maryann, V. B. (2013). Effect of application of organic and mineral soil amendments in a continuous cropping system for 10 years on chemical and physical properties of an Alfisol in Northen Guinea Savanna Zone. International Journal of Agricultural Policy and Research, 1, 116-123.

Oades, J. M., Gillman, G. P., Uehara, G., Hue, N. V., van Noordwijk, M., Robertson, G. P., \& Wada, K. (1989). Interactions of soil organic matter and variable-charge clays. In D. C. Coleman, J. M. Oades, \& G. Uehara (Eds.), Dynamics of soil organic matter in tropical ecosystems (pp. 69-95). Honolulu: University of Hawaii Press.

Olaniran, A. O., Balgobind, A., \& Pillay, B. (2013). Bioavailability of heavy metals in soil: impact on microbial biodegradation of organic compounds and possible improvement strategies. International Journal of Molecular Sciences, 14(5), 10197-10228.
Opala, P. A., Okaleb, J. R., \& Othieno, C. O. (2012). Effects of organic and inorganic materials on soil acidity and phosphorus availability in a soil incubation study. ISRN Agronomy, 597216, 10. https://doi.org/10.5402/2012/597216.

Placek, A., Grobelak, A., Hiller, J., Stępień, W., Jelonek, P., Jaskulak, M., \& Kacprzak, M. (2017). The role of organic and inorganic amendments in carbon sequestration and immobilization of heavy metals in degraded soils. Journal of Sustainable Development of Energy, Water and Environment Systems, 5, 509-517.

Polo, M. S., \& Utrilla, J. R. (2002). Adsorbent-adsorbate interactions in the adsorption of $\mathrm{Cd}$ (II) and $\mathrm{Hg}$ (II) on ozonized activated carbons. Environmental Science and Technology, 36, 3850-3854. https://doi.org/10.1021/es0255610.

Puga, A. P., Abreu, C. A., Melo, L. C., Paz-Ferreiro, J., \& Beesley, L. (2015). Cadmium, lead, and zinc mobility and plant uptake in a mine soil amended with sugarcane straw biochar. Environmental Science and Pollution Research, 22, 1760617614. https://doi.org/10.1007/s11356-015-4977-6.

Qian, T., Wang, Y., Fan, T., Fang, G., \& Zhou, D. (2016). A new insight into the immobilization mechanism of $\mathrm{Zn}$ on biochar: the role of anions dissolved from ash. Scientific Reports, 6, 33630. https://doi.org/10.1038/srep33630.

Rieuwerts, J., Thornton, I., Farago, M., \& Ashmore, M. (1998). Factors influencing metal bioavailability in soils: preliminary investigations for the development of a critical loads approach for metals. Chemical Speciation and Bioavailability, 10 (2), 61-75. https://doi.org/10.3184 /095422998782775835.

Sabir, M., Ali, A., Zia-ur-Rehman, M., \& Hakeem, K. R. (2014). Contrasting effects of farmyard manure (fym) and compost for remediation of metal contaminated soil. International Journal of Phytoremediation, 17(7), 613-621. https://doi. org/10.1080/15226514.2014.898019.

Shaha, S. C., Kashem, M. A., \& Osman, K. T. (2012). Effect of lime and farmyard manure on the concentration of cadmium in water spinach (Ipomoea aquatica). ISRN Agronomy, 719432. https://doi.org/10.5402/2012/719432.

Simmler, M., Ciadamidaro, L., Schulin, R., Madejón, P., Reiser, R., Clucas, L., Weber, P., \& Robinson, B. (2013). Lignite reduces the solubility and plant uptake of cadmium in pasturelands. Environmental Science and Technology, 47, 4497-4504.

Singh, A. K., Sarkar, A. K., Kumar, A., \& Singh, B. P. (2009). Effect of long-term use of mineral fertilizers, lime and farmyard manure on the crop yield, available plant nutrient and heavy metal status in acidic loam soil. Journal of the Indian Society of Soil Science, 57, 362-365.

Skłodowski, P., Maciejewska, A., \& Kwiatkowska, J. (2006). The effect of organic matter from brown coal on bioavailability of heavy metals in contaminated soils. In I. Twardowska, H. E. Allen, M. M. Häggblom, S. Stefaniak (Eds.), Soil and water pollution monitoring, protection and remediation (pp. 299307). NATO Science Series, vol 69. Springer, Dordrecht. https://doi.org/10.1007/978-1-4020-4728-2 19.

Skodras, G., Kokorotsikos, P., \& Serafidou, M. (2014). Cation exchange capability and reactivity of low rank coal and chars. Central European Journal of Chemistry, 12(1), 33-43. https://doi.org/10.2478/s11532-013-0346-9.

Soares, M. R., Casagrande, J. C., \& Mouta, E. R. (2011). Nickel adsorption by variable charge soils: effect of $\mathrm{pH}$ and ionic 
strength. Brazilian Archives of Biology and Technology, 54, 207-220.

Sokołowska, Z., Kwiatkowska, J., \& Maciejewska, A. (2007). Adsorption of water vapour on brown coals of different origin. Acta Agrophysica, 9((2)(147)), 481-494.

Stouraiti, C., Xenidis, A., \& Paspaliaris, I. (2002). Reduction of $\mathrm{Pb}, \mathrm{Zn}$ and $\mathrm{Cd}$ availability from tailings and contaminated soils by the application of lignite fly ash. Water, Air, and Soil Pollution, 137, 247-265. https://doi.org/10.1023 /A:1015507017799.

Toth, G., Hermann, T., Szatmari, G., \& Pasztor, L. (2016). Maps of heavy metals in the soils of the European Union and proposed priority areas for detailed assessment. Science of the Total Environment, 565, 1054-1062.

Turgay, O. C., Karaca, A., Unver, S., \& Tamer, N. (2011). Effects of coal-derived humic substance on some soil properties and bread wheat yield. Communications in Soil Science and Plant Analysis, 42, 1050-1070. https://doi.org/10.1080 /00103624.2011.562586.

Uchimiya, M., Lima, I. M., Thomas, K. K., Chang, S., Wartelle, L. H., \& Rodgers, J. E. (2010). Immobilization of heavy metal ions (CuII, CdII, NiII, and PbII) by broiler litter-derived biochars in water and soil. Journal of Agricultural and Food Chemistry, 58, 5538-5544.

Uzinger, N., Rékási, M., Draskovits, E., \& Anton, A. (2014). Stabilization of $\mathrm{Cr}, \mathrm{Pb}$ and $\mathrm{Zn}$ in soil using lignite. Soil and Sediment Contamination, 23, 270-286. https://doi. org/10.1080/15320383.2014.826620.

Violante, A., Cozzolino, V., Perelomov, L., Caporale, A., \& Pigna, M. (2010). Mobility and bioavailability of heavy metals and metalloids in soil environments. Journal of Soil Science and Plant Nutrition, 10, 268-292 https://doi. org/10.4067/S0718-95162010000100005.

Woldetsadik, D., Drechsel, P., Keraita, B., Marschner, B., Itanna, F., \& Gebrekidan, H. (2016). Effects of biochar and alkaline amendments on cadmium immobilization, selected nutrients and cadmium concentrations of lettuce (Lactuca sativa) in two contrasting soils. Springerplus, 5, 397. https://doi. org/10.1186/s40064-016-2019-6.

Wuana, R. A., \& Okieimen, F. E. (2011). Heavy metals in contaminated soils: a review of sources, chemistry, risks and best available strategies for remediation. ISRN Ecology, 402647. https://doi.org/10.5402/2011/402647.

Xue, R., Shen, Y., \& Marschner, P. (2017). Soil water content during and after plant growth influence nutrient availability and microbial biomass. Journal of Soil Science and Plant Nutrition, 17, 702-715. https://doi.org/10.4067/S071895162017000300012.

Yang, X., Liu, J., McGrouther, K., Huang, H., Lu, K., Guo, X., et al. (2016). Effect of biochar on the extractability of heavy metals $(\mathrm{Cd}, \mathrm{Cu}, \mathrm{Pb}$, and $\mathrm{Zn})$ and enzyme activity in soil. Environmental Science and Pollution Research, 23, 974 984.

Yuan, J. H., Xu, R. K., Qian, W., \& Wang, R. H. (2011). Comparison of the ameliorating effects on an acidic ultisol between four crop straws and their biochars. Journal of Soils and Sediments, 11(5), 741-750.

Zgorelec, Ž., Grahovac, P. A., Jurković, V., Gandjaeva, L., \& Maurović, N. (2019). Comparison of two different CEC determination methods regarding the soil properties. Agriculturae Conspectus Scientificus, 84(2), 151-158.

Zhou, D., Liu, D., Gao, F., Li, M., \& Luo, X. (2017). Effects of biochar-derived sewage sludge on heavy metal adsorption and immobilization in soils. International Journal of Environmental Research and Public Health, 14(7), 681. https://oi.org/10.3390/ijerph14070681.

Publisher's Note Springer Nature remains neutral with regard to jurisdictional claims in published maps and institutional affiliations. 